\title{
Levantamento da família Orchidaceae no Morro Santa Cruz, Municípios de Corumbá e Ladário, Mato Grosso do Sul, Brasil
}

\author{
Diógenes Parabá Rodriguez ${ }^{1}$, Fábio de Barros ${ }^{2,4}$, Geraldo Alves Damasceno Junior ${ }^{3}$ e Ieda Maria Bortolotto ${ }^{3}$
}

Recebido: 19.03.2009; aceito: 16.10.2009

ABSTRACT - (Floristic survey of the family Orchidaceae in the Santa Cruz Hills, Municipalities of Corumbá and Ladário, Mato Grosso do Sul State, Brazil). A survey of the orchids found at the "Santa Cruz" Hills, Municipalities of Corumbá and Ladário, Mato Grosso do Sul State, Brazil was carried out. Collections were achieved weekly from January to October, 1999 , trying to cover different altitudes in that parts of the hills with vegetation still preserved. The herbarium materials were housed at herbarium COR with duplicates at CPAP, and SP. Twenty one orchid species belonging to 19 genera were found. Seven are terrestrial - Aspidogyne longicornu, Cyrtopodium virescens, Epistephium sclerophyllum, Habenaria juruenensis, Habenaria polycarpa, Oeceoclades maculata, and Sarcoglottis curvisepala -, one hemiepiphytic - Vanilla palmarum -, and the remaining are holoepiphytic - Acianthera pubescens, Alatiglossum macropetalum, Campylocentrum hasslerianum, Cattleya nobilior, Encyclia conchaechila, Epidendrum coronatum, Epidendrum densiflorum, Isochilus linearis, Lophiaris morenoi, Octomeria warmingii, Polystachya concreta, Sophronitis cernua, and Xylobium foveatum. Identification key, descriptions of examined materials and illustrations were provided.

Key words: Mato Grosso do Sul, Orchidaceae, orchids, Santa Cruz Hills

RESUMO - (Levantamento da família Orchidaceae no Morro Santa Cruz, Municípios de Corumbá e Ladário, Mato Grosso do Sul, Brasil). É apresentado um levantamento das espécies da família Orchidaceae encontradas no Morro Santa Cruz, Municípios de Corumbá e Ladário, Mato Grosso do Sul, Brasil. Foram realizadas coletas semanais, de janeiro a outubro de 1999, em diferentes altitudes, nas partes do morro ainda com vegetação preservada. As exsicatas foram incorporadas ao herbário COR, com duplicatas enviadas aos herbários CPAPe SP. Foram coletadas 21 espécies, pertencentes a 19 gêneros, sete terrícolas - Aspidogyne longicornu, Cyrtopodium virescens, Epistephium sclerophyllum, Habenaria juruenensis, Habenaria polycarpa, Oeceoclades maculata e Sarcoglottis curvisepala, uma hemiepífita - Vanilla palmarum, e as demais holoepífitas Acianthera pubescens, Alatiglossum macropetalum, Campylocentrum hasslerianum, Cattleya nobilior, Encyclia conchaechila, Epidendrum coronatum, Epidendrum densiflorum, Isochilus linearis, Lophiaris morenoi, Octomeria warmingii, Polystachya concreta, Sophronitis cernua, e Xylobium foveatum. São apresentados uma chave para identificação das espécies, descrições, lista de material examinado e comentários pertinentes, bem como ilustrações de dez espécies estudadas.

Palavras-chave: Mato Grosso do Sul, Morro Santa Cruz, Orchidaceae, orquídeas

\section{Introdução}

A família Orchidaceae é altamente especializada e considerada, tanto pela predominância do hábito epifítico quanto pelas adaptações à polinização predominantemente entomófila. Embora as orquídeas apareçam em quase todos os ambientes vegetados do globo, sua distribuição não é uniforme - a maioria das espécies ocorre nos trópicos, especialmente nos Neotrópicos (Pridgeon 1995), sendo que as epífitas estão limitadas aos ambientes tropicais e subtropicais (Dressler 1981). Mesmo nos trópicos, elas se distribuem diferentemente de acordo com gradientes de altitude (Pridgeon 1995) e mostram preferência por determinadas fisionomias vegetacionais dentro de uma mesma área (p. ex., Ribeiro et al. 1994). Enquanto a maioria das famílias de Fanerógamas possui menos de 100 espécies (Braga 1977), estimativas dão conta de cerca de 24.500 espécies naturais de orquídeas (Dressler 2005). Esse enorme tamanho da família traz consigo diversos problemas taxonômicos.

A família Orchidaceae pode ser reconhecida pelo seguinte conjunto de características: sementes microscópicas e sem endosperma, flores trímeras,

1. R. Adventor Divino de Almeida s/n, lote 14 J, Jardim Noroeste, 79045-070 Campo Grande, MS, Brasil.

2. Instituto de Botânica, Caixa Postal 3005, 01061-970 São Paulo, SP, Brasil

3. Universidade Federal de Mato Grosso do Sul, Centro de Ciências Biológicas e da Saúde, Departamento de Biologia, Caixa Postal 549, 79070-900 Campo Grande, MS, Brasil

4. Autor para correspondêencia: fdebarros@terra.com.br 
zigomorfas, ovário ínfero, uma das pétalas modificada em labelo, filetes e estiletes unidos numa estrutura única denominada ginostêmio (ou coluna), pólen geralmente unido em polínias, folhas com inervação paralela e sistema radicular fasciculado. Segundo Pridgeon et al. (1999), a família Orchidaceae está dividida em cinco subfamílias: Apostasioideae, Cypripedioideae, Orchidoideae, Vanilloideae e Epidendroideae, reconhecíveis, principalmente, por características relacionadas ao ginostêmio e às polínias.

Desde o século XVIII a flora mato-grossense vem sendo estudada por botânicos brasileiros e estrangeiros (Lima 1985). Frederico Carlos Hoehne foi um dos botânicos que mais contribuiu para o conhecimento da família Orchidaceae para o Estado de Mato Grosso, tendo percorrido, entre os anos de 1908 e $1923,7.350 \mathrm{~km}$ nesse Estado, durante seus trabalhos como Botânico da Comissão Rondon, tendo listado 149 espécies de orquídeas (Hoehne 1915). Devese ressaltar aqui que, à época de Hoehne, o Estado de Mato Grosso abrangia também a área que, hoje, constitui o Estado do Mato Grosso do Sul.

Pott \& Pott $(1994,1999)$ citaram 22 espécies de orquídeas para o Pantanal, sendo que dois dos binômios citados [Stenorrhynchus australis Lindl. e Stenorhynchus lanceolatus (Aubl.) L.C. Rich.] representam, segundo Garay (1980) uma única espécie [Sacoila lanceolata (Aubl.) Garay]. Trabalhando com informações dos herbários europeus e do herbário MBM, Dubs (1998) listou 116 espécies de orquídeas para os Estados de Mato Grosso e Mato Grosso do Sul.

Existem poucas informações sobre Orchidaceae ocorrentes no Município de Corumbá (MS); não há, inclusive, uma chave de identificação de espécies dessa família, que poderia auxiliar os pesquisadores em levantamentos florísticos na região. No levantamento florístico realizado nos campos de cerrado do Morro Urucum, no Município de Corumbá, Bortolotto et al. (1999) citaram a ocorrência de apenas duas espécies de Orchidaceae: Epistephium sclerophyllum Lindl. e Habenaria sp. Damasceno Junior (1998, 2005), realizou estudos preliminares na vegetação do Morro Santa Cruz, registrando a ocorrência de apenas três espécies da família Orchidaceae. Esse autor enfatizou, no entanto, a necessidade de se realizar mais estudos complementares na área. Chaparro (1994) apresentou um levantamento da família Orchidaceae no Município de Corumbá, listando 23 espécies, seis das quais foram encontradas em um único ponto do Morro Santa Cruz. Esse foi um dos motivos para se intensificar as coletas nesse morro, além do fato de que as coletas realizadas por Chaparro (1994) não cobriram as diferentes altitudes da área.

Os objetivos do presente trabalho foram realizar um levantamento de Orchidaceae e elaborar uma chave para identificação das espécies encontradas no Morro Santa Cruz, onde se localiza a Mineração Corumbaense Reunidas S.A. Este trabalho é parte integrante do Projeto "Vitória Régia" (Bortolotto et al. 1999) que teve como objetivo geral caracterizar a fauna e a flora da microbacia da Baia Negra, no Pantanal sul-mato-grossense.

São apresentadas: chave para identificação das espécies, descrições, lista de material examinado, observações de cunho taxonômico e fitogeográfico, e ilustrações de parte das espécies. Sinônimos foram fornecidos apenas quando o nome considerado na sinonímia é amplamente utilizado na literatura.

\section{Material e métodos}

A área de estudos consiste na morraria Santa Cruz, situada nos Municípios de Corumbá e Ladário, Mato Grosso do Sul, aproximadamente nas coordenadas $19^{\circ} 12^{\prime}$ 'S e $57^{\circ} 34^{\prime} \mathrm{W}$ (área central), com altitude variando de 220 a 1.065 m s.m..

A vegetação da morraria Santa Cruz varia desde floresta decídua nas áreas mais baixas do morro até floresta semidecídua, nas altitudes superiores a $400 \mathrm{~m}$ (Damasceno Junior 2005). Nas cotas superiores a 800 m a mata é gradualmente substituída por vegetação de cerrado lato sensu, com fisionomia de cerrado stricto sensu, mudando gradativamente para campo com o aumento da altitude (Damasceno Junior 2005). Os campos da região variam de campo limpo de cerrado até campo sujo, surgindo sobre solos que vão de litólicos até cambissolos. Nas áreas mais íngremes, com afloramentos de rochas, há uma gradação para vegetação rupestre (Bortolotto et al. 1999). É importante ressaltar que o conceito de cerrado lato sensu aqui adotado segue a classificação de Coutinho (1978), na qual os campos limpos estão incluídos

Segundo a classificação de Köppen, o clima da região de Corumbá é do tipo AWA, ou seja, clima tropical de altitude, megatérmico (temperatura média do mês mais frio superior a $18{ }^{\circ} \mathrm{C}$ ), com inverno seco e chuvas no verão (Soriano 1997).

As coletas foram realizadas semanalmente, no período de janeiro a outubro de 1999, com algumas coletas complementares posteriores. O morro foi subdividido em quatro setores, indo das menores para 
as maiores altitudes. $\mathrm{O}$ primeiro setor, com altitude iniciando aos $220 \mathrm{~m}$, o segundo aos $420 \mathrm{~m}$, o terceiro, aos $620 \mathrm{~m}$ e o quarto, a partir dos $820 \mathrm{~m}$, até alcançar a cota máxima de 1.065 m.s.m.

Os exemplares encontrados férteis foram coletados e fotografados, suas características foram anotadas em fichas e foram prensados, no campo, para posterior inclusão e montagem no herbário COR, com duplicatas enviadas para os herbários CPAP e SP. A desidratação do material seguiu os procedimentos tradicionais, apresentados em Fidalgo \& Bononi (1984). Flores foram preservadas em álcool $70 \%$ ou FAA para posterior confecção das ilustrações. Plantas encontradas estéreis foram, quando possível, levadas para cultivo, sendo amostradas e identificadas por ocasião da floração.

No laboratório, o material foi identificado com auxílio de bibliografia especializada, especialmente os trabalhos de Lindley (1830-1840), Rodrigues (1877, 1882), Cogniaux (1893-1896, 1898-1902, 1904-1906), Hoehne (1942, 1945, 1949, 1953), Pabst \& Dungs (1975, 1977), Dunsterville \& Garay (1979), Sprunger $(1986,1996)$ e Castro Neto \& Campacci $(2000,2003)$. Seguiu-se, basicamente, a nomenclatura adotada por Pabst \& Dungs $(1975,1977)$, mas com várias atualizações nomenclaturais. Quando necessário, a identificação foi acompanhada de comparação com exsicatas previamente identificadas dos herbários COR e SP.

\section{Resultados e Discussão}

Foram coletadas, no Morro Santa Cruz, 21 espécies de orquídeas, pertencentes a 19 gêneros diferentes: Acianthera pubescens (Lindl.) Pridgeon \& M.W. Chase, Alatiglossum macropetalum (Lindl.) Baptista, Aspidogyne longicornu (Cogn.) Garay, Campylocentrum hasslerianum Hoehne, Cattleya nobilior Rchb. f., Cyrtopodium virescens Rchb. f. \& Warm., Encyclia conchaechila (Barb. Rodr.) Porto \& Brade, Epidendrum coronatum Ruiz \& Pávon, Epidendrum densiflorum Hook., Epistephium sclerophyllum Lindl., Habenaria juruenensis Hoehne, Habenaria polycarpa Hoehne, Isochilus linearis (Jacq.) R. Br., Lophiaris morenoi (Dodson \& Luer) Braem, Octomeria warmingii Rchb.f., Oeceoclades maculata (Lindl.) Lindl., Polystachya concreta (Jacq.) Garay \& Sweet, Sarcoglottis curvisepala Szlach. \& Rutk., Sophronitis cernua Lindl. Vanilla palmarum (Salzm. ex Lindl.) Lindl.e Xylobium foveatum (Lindl.) Nichols.

Entre as espécies encontradas, sete são terrícolas, 13 são epífitas (uma hemiepífita e 12 holoepífitas), e uma é, alternativamente, epífita ou rupícola; seis delas são novas citações para o Estado do Mato Grosso do Sul e uma, nova citação para o Brasil. Considerando as subfamílias estabelecidas no sistema de Pridgeon et al. (1999), 15 pertencem à subfamília Epidendroideae quatro à subfamília Orchidoideae e duas à subfamília Vanilloideae, denotando forte predominância das Epidendroideae. Essas informações estão resumidas na tabela 1.

Das vinte e uma espécies de Orchidaceae citadas por Pott \& Pott (1999) para o Pantanal, três foram encontradas no Morro Santa Cruz: Cattleya nobilior, Cyrtopodium virescens e Vanilla palmarum. Estas três espécies também fazem parte da lista de 116 espécies de orquídeas dos Estados de Mato Grosso e Mato Grosso do Sul, listadas por Dubs (1998). Dessa lista, outras nove espécies também foram coletadas no Morro Santa Cruz, no presente trabalho: Aspidogyne longicornu, Epidendrum coronatum, Epistephium sclerophyllum, Habenaria juruenensis, Habenaria polycarpa, Oeceoclades maculata, Polystachya concreta e Xylobium foveatum.

No morro Santa Cruz, o número de espécies da família Orchidaceae é equivalente ao listado por Pott \& Pott (1999) para toda a planície de inundação do Pantanal, com baixa sobreposição de espécies, o que torna a região especial. Dos ambientes coletados, as florestas estacionais semidecíduas apresentaram o maior número de espécies da família (13), seguidas pelos cerrados (cinco - desde cerrado sensu stricto até campo limpo, cf. Coutinho 1978), florestas de galeria (cinco) e florestas decíduas (duas). Esse é um resultado esperado, uma vez que as florestas estacionais semidecíduas e as fisionomias de cerrado concentram-se acima de $400 \mathrm{~m}$ de altitude nessa área onde, segundo Damasceno Junior (2005), existe maior concentração de chuvas e umidade, pois as nuvens concentram-se nessa faixa altitudinal por ocasião da entrada das frentes frias. Já as florestas decíduas apresentaram baixo número de espécies, provavelmente devido à baixa umidade a que estão sujeitas. Segundo Damasceno Junior (2005), a precipitação nas áreas de floresta decídua pode ser $30 \%$ a $40 \%$ menor que nas áreas mais altas do morro.

Assim, é urgente que se pense em unidades de conservação que possam manter a diversidade de espécies de orquídeas que ocorrem tanto nas florestas como nas áreas mais abertas de cerrado. As áreas de floresta semidecídua, mais ricas em espécies, estão concentradas nas partes mais altas dos morros da região, ocorrendo como uma faixa estreita entre a 
Tabela 1. Espécies de Orchidaceae ocorrentes no Morro Santa Cruz, com indicação da subfamília a que pertencem (no sistema de Pridgeon et al. 1999), tipo de hábito e observações quanto à constatação de novas ocorrências para o Mato Grosso do Sul e o Brasil (TR = terrícola; $\mathrm{HO}=$ holoepífita; $\mathrm{HE}=$ hemiepífita; $\mathrm{RP}=$ rupícola).

Table 1. Species of Orchidaceae from the Morro Santa Cruz, with corresponding subfamilies (according to the system of Pridgeon et al. 1999), type of habit and observations concerning new records to the state of Mato Grosso do Sul and to Brazil (TR = terrestrial; $\mathrm{HO}=$ holoepiphyte; $\mathrm{HE}=$ hemiepiphyte; $\mathrm{RP}=$ rupicolous).

\begin{tabular}{llll}
\hline ESPÉCIE & SUBFAMÍLIA & HÁBITO & OBSERVAÇÕES \\
\hline Acianthera pubescens & Epidendroideae & HO & primeira citação para o MS \\
Alatiglossum macropetalum & Epidendroideae & HO & \\
Aspidogyne longicornu & Orchidoideae & TR & primeira citação para o Brasil \\
Campylocentrum hasslerianum & Epidendroideae & HO & \\
Cattleya nobilior & Epidendroideae & HO (RP) & \\
Cyrtopodium virescens & Epidendroideae & TR & \\
Encyclia conchaechila & Epidendroideae & HO & \\
Epidendrum coronatum & Epidendroideae & HO & \\
Epidendrum densiflorum & Epidendroideae & HO & \\
Epistephium sclerophyllum & Vanilloideae & TR & \\
Habenaria juruenensis & Orchidoideae & TR & \\
Habenaria polycarpa & Orchidoideae & TR & \\
Isochilus linearis & Epidendroideae & HO & \\
Lophiaris morenoi & Epidendroideae & HO & \\
Octomeria warmingii & Epidendroideae & HO cira citação para o MS \\
Oeceoclades maculata & Epidendroideae & TR & \\
Polystachya concreta & Epidendroideae & HO & \\
Sarcoglottis curvisepala & Orchidoideae & TR & \\
Sophronitis cernua & Epidendroideae & HO & \\
Vanilla palmarum & Vanilloideae & HE & primeira citação para o MS \\
Xylobium foveatum & Epidendroideae & HO & primeira citação para o MS \\
\hline & & & primeira citação para o MS \\
\hline
\end{tabular}

floresta decídua e as áreas de cerrado mais aberto. Essas áreas estão sob forte pressão antrópica por conta da sua substituição por pastagem e possível uso para mineração de ferro a céu aberto. Segundo Pott et al. (2000), até o ano de 2000, cerca de $45 \%$ das áreas de floresta da região haviam sido convertidas em pastagem ou desmatadas, dando lugar a capoeiras.

Os minérios de ferro utilizados na região são encontrados principalmente nos solos das áreas de campo cerrado, onde foram registradas cinco espécies. A vegetação dessas áreas e os solos são completamente retirados durante o processo de lavra. Considerando esses fatos, e que as florestas semidecíduas são vizinhas dessas formações, é importante que as mineradoras que atuam na região tenham especial cuidado com as espécies de Orchidaceae na restauração das áreas degradadas. Isso se aplica especialmente àquelas espécies que, no presente trabalho, estão sendo registradas pela primeira vez para o Estado e para o Brasil, pois ainda não são conhecidos os seus padrões de distribuição, e não se pode correr o risco de eliminálas destes ambientes, promovendo extinções locais por falta de conhecimento.

\section{Chave para a identificação das espécies de Orchidaceae ocorrentes no Morro Santa Cruz}

1. Plantas terrícolas

2. Caule intumescido em pseudobulbo

3. Flores sem calcar; inflorescência em panícula; pseudobulbos homoblásticos; folhas verdes concolores 6. Cyrtopodium virescens

3. Flores calcaradas; inflorescência em racemo, raramente ramificadas; pseudobulbos heteroblásticos; folhas verde-escuras marmorizadas de verde-claro 16. Oeceoclades maculata 
2. Caule não intumescido em pseudobulbo

4. Folhas ausentes na floração; sépalas subcarnosas, as laterais com base decurrente no ovário 18. Sarcoglottis curvisepala

4. Folhas presentes na floração; sépalas membranáceas a herbáceas, as laterais com base não decurrente no ovário

5. Pólen não formando polínias distintas; folhas coriáceas, rígidas; flores destituídas de calcar 10. Epistephium sclerophyllum

5. Pólen em polínias sécteis; folhas membranáceas; flores calcaradas

6. Caule prostrado na porção basal; folhas pecioladas 3. Aspidogyne longicornu

6. Caule ereto em toda sua extensão; folhas sésseis

7. Pétala claramente bipartida; folhas 1-2 cm larg.; flores brancas

11. Habenaria juruenensis

7. Pétala inteira, apenas com um dente filiforme-assovelado próximo à base; folhas 3,9-6,5 cm larg.; flores verde-claras 12. Habenaria polycarpa

1. Plantas epífitas ou rupícolas

8. Plantas com crescimento monopodial

9. Epífita (holoepífita); folhas 5-5,5 cm compr., ca. $8 \mathrm{~mm}$ larg., com ápice fortemente assimétrico; grãos de pólen fortemente unidos, formando polínias cartilaginosas; flores calcaradas 4. Campylocentrum hasslerianum

9. Hemiepífita; folhas 8,5-12,5 cm compr., 3,4-4,5 cm larg., com ápice obtuso; grãos de pólen laxamente unidos, não formando polínias distintas; flores destituídas de calcar 20. Vanilla palmarum

8. Plantas com crescimento simpodial

10. Pseudobulbos ausentes

11. Uma só folha no ápice de cada caule; ovário articulado com o pedicelo

12. Inflorescência em racemo; flores predominantemente translúcido-vinosas; ovário e sépalas externamente pubérulos 1. Acianthera pubescens

12. Inflorescência em fascículo na axila da folha; flores branco-amareladas; ovário e sépalas externamente glabros 15. Octomeria warmingii

11. Várias folhas dísticas ao longo dos caules; ovário não articulado com o pedicelo

13. Flores lilases a róseas; sépalas coalescentes até cerca de 2/3 do comprimento; labelo inteiro; folhas com lâmina linear-oblongas, ca. $3 \mathrm{~mm}$ larg. ....... 13. Isochilus linearis

13. Flores castanho-esverdeadas ou combinando verde, creme-esverdeado e branco; sépalas totalmente livres entre si; labelo trilobado; folhas com lâmina elíptica, elíptico-lanceolada ou estreitamente-obovada, 1,2-5 cm larg.

14. Inflorescência em racemo; sépalas e pétalas castanho-esverdeadas; labelo amarelo-esverdeado, ca. 16 mm larg.; ginostêmio creme-esverdeado, ca. 1,3 cm compr. 8. Epidendrum coronatum

14. Inflorescência em panícula; sépalas e pétalas verdes a creme-esverdeadas; labelo branco a branco-esverdeado, 9-11 mm larg.; ginostêmio branco, $0,8-0,9 \mathrm{~cm}$ compr. 9. Epidendrum densiflorum

10. Pseudobulbos presentes

15. Inflorescência lateral

16. Folhas com várias nervuras paralelas salientes na face abaxial; flores de cor creme; labelo envolvendo o ginostêmio; base do ginostêmio com pé distinto 21. Xylobium foveatum

16. Folhas com uma só nervura central saliente na face abaxial; flores predominantemente brancas ou amarelas com manchas castanhas; labelo formando ângulo reto ou quase com o ginostêmio; base do ginostêmio destiduída de pé 
17. Flores predominantemente brancas; pseudobulbos ca. $4 \mathrm{~mm}$ compr., ápice 1-foliado; labelo ca. $3 \mathrm{~mm}$ compr. 14. Lophiaris morenoi

17. Flores predominantemente amarelas; pseudobulbos com ápice 1(2)-foliado, 2,5-5,5 cm compr.; labelo 1,2-1,7 cm compr. 2. Alatiglossum macropetalum

15. Inflorescência terminal

18. Flores grandes (sépalas 4,5-5,5 $\square$ 1,3-1,5 cm) e vistosas, predominantemente róseo-lilases 5. Cattleya nobilior

18. Flores menores, (sépalas até $2 \square 0,4 \mathrm{~cm}$ ), cor de mostarda, verde-amareladas, creme-esverdeadas ou vermelhas

19. Pseudobulbos 1-foliados; flores vermelhas; labelo inteiro 19. Sophronitis cernua

19. Pseudobulbos 2-4-foliados; flores verde-amareladas, creme-esverdeadas, até mostarda; labelo trilobado

20. Base da coluna não formando mento com as sépalas laterais; disco do labelo destituído de tufo de tricomas; labelo ca $9 \mathrm{~mm}$ larg. 7. Encyclia conchaechila

20. Base da coluna formando mento evidente com as sépalas laterais; disco do labelo coberto por tufo de tricomas brancos; labelo ca.

$2,5 \mathrm{~mm}$ larg. 17. Polystachya concreta

1. Acianthera pubescens (Lindl.) Pridgeon \& M.W. Chase, Lindleyana 16(4): 245.2001 $\equiv$ Pleurothallis pubescens Lindl. In Hook., Comp. Bot. Mag. 2: 355. 1836.

= Pleurothallis smithiana Lindl., Bot. Reg. 29 (misc.): 57. 1843.

Figuras 1-4

Epífita (holoepífita), simpodial; raízes filiformes, fasciculadas. Rizoma ca. 1,5 cm entre caulomas; cauloma 5-8 cm compr., ca. 0,2 cm larg., cilíndrico, não intumescido em pseudobulbo, 1-foliado. Folhas 5-8 cm compr., 2-3 cm larg., oblongas, carnosas. Inflorescência 3-4 cm compr., em racemo, apoiada sobre a lâmina foliar, base com uma espata bem desenvolvida. Flores creme-translúcidas, com riscos e máculas vinosos; pedicelo + ovário ca. $2 \mathrm{~mm}$ compr., pubérulos; ovário articulado com o pedicelo; segmentos florais eretos; sépalas externamente pubérulas, a dorsal ca. $6 \mathrm{~mm}$ compr., 1,5 mm larg., oblonga, as laterais ca. $6 \mathrm{~mm}$ compr., coalescentes; pétalas ca. $2 \mathrm{~mm}$ compr., $1 \mathrm{~mm}$ larg., obovadas, ápice agudo, margem curtamente ciliada; labelo ca. $2,5 \mathrm{~mm}$ compr., 1,5 mm larg., trilobado, âmbito oblongoobovado, lobos laterais curtos, sub-trapezoidais, eretos; ginostêmio ca. 1,5 mm compr., 0,5 mm larg.; polínias 2, ceróides, dotadas apenas de caudículas reduzidas. Frutos não vistos

Material examinado: BRASIL. Mato Grosso do Sul: Corumbá; Morro Santa Cruz, 23-IX-1994, fr., M.A.C. Chaparro et al. 4 (COR, CPAP); idem, 20-I-1999, fl., fr., D.P. Rodriguez 2 (COR, SP); idem, cultivada na Seção de Orquidário do Instituto de Botânica, florindo em 15-IV-2002, fl., F. Barros s.n. (SP409469).

Caracterizada pelo pequeno porte, flores creme-translúcidas com riscos e máculas vinosos, externamente pubérulas e sépalas laterais coalescentes entre si. Encontrada apenas em mata fechada e com pouca luminosidade, sobre árvores a 2-3 m de altura, em altitudes de 750-800 m. É a primeira citação efetiva desta espécie para o Estado de Mato Grosso do Sul, pois Chaparro (1994) já havia constatado sua presença no Estado, mas deixou a identidade em dúvida, utilizando o binômio Pleurothallis aff. smithiana Lindl. Ocorre desde o México em direção à América Central, Índias Ocidentais, Venezuela, Guianas, Guiana Francesa, Suriname, Colômbia, Equador, Peru, Bolívia, Brasil, Paraguai e Argentina (Werkhoven 1986, Dodson \& Benett 1989, Instituto de Botánica Darwinion 2009). No Brasil, ocorre mais comumente nas florestas costeiras, nos Estados da BA, ES, RJ, SP, PR, SC, RS e MS.

2. Alatiglossum macropetalum (Lindl.) Baptista, Colet. Orquídeas Brasil. 3: 88. 2006 三 Oncidium macropetalum Lindl., Sert. Orchid. sub t. 48. 1841.

Epífita (holoepífita), simpodial. Rizoma inconspícuo; cauloma 2,5-5,5 cm compr., 1,4-2,2 $\mathrm{cm}$ larg., intumescido em pseudobulbo, ovóide, lateralmente compresso, longitudinalmente sulcado, ápice 1(2)-foliado, base com 2-3 bainhas foliadas. Folhas apicais 9,5-20 cm compr., 1,4-1,8 
cm larg., subcoriáceas, oblongas, ápice agudo a curtamente acuminado, base atenuada, conduplicada, somente a nervura central saliente na face abaxial. Inflorescência lateral, em panícula, geralmente pauci-ramosa; pedúnculo 19-35,5 cm compr. Flores predominantemente amarelas; pedicelo + ovário 1,1-2 cm compr.; sépalas elíptico-lanceoladas a obovadoespatuladas, ápice agudo a curtamente acuminado, amarelas com manchas castanhas, margens onduladas, a dorsal 6,5-9 mm compr., 3-4 mm larg., levemente côncava, base curtamente atenuada, as laterais 9-11 mm compr., 2,5-3 mm larg., coalescentes na base em $1 / 3$ a $1 / 2$ do comprimento; pétalas $10-13 \mathrm{~mm}$ compr., 9-13 mm larg., largamente obovado-suborbiculares, ápice emarginado, curtamente apiculado, base curtamente unguiculada, margem ondulada; labelo 12-17 mm compr., 11-12 mm larg., trilobado, amarelo, âmbito obovado-subquadrado, subpandurado, base curtissimamente unguiculada, margens ligeiramente onduladas, lobos laterais suborbiculares, 2-3,5 mm diâm., lobo central 6-9 mm compr., 11-14 mm larg., reniforme, ápice profundamente emarginado, curtamente apiculado, sinus entre os lobos com margem curtamente denticulada, disco com calo complexo; ginostêmio curto com duas asas subquadrangulares adjacentes à cavidade estigmática; polínas cartilaginosas, com estipe alongado e viscídio ovalado. Frutos não vistos.

Material examinado: BRASIL. Mato Grosso Do Sul: Corumbá, Morro Santa Cruz, Mineração Corumbaense, 24-VI-2002, fl., D.P. Rodriguez 63 (COR, SP).

Material adicional examinado: BRASIL. GoIÁs: Niquelândia, pr. do encontro do Rio Maranhão com o Rio das Almas, 5-V-1998, fl., B.M.T. Walter et al. 4126 (SP); Mato Grosso do Sul: Coxim, cultivada no Rio de Janeiro, IX-1914, fl., F.C. Hoehne 49 (SP); Minas Gerais: Unaí, 16²12'27”S, 47¹9'20”W, fl., A.A. Santos \& J.B. Pereira 2056 (SP).

A espécie é mais conhecida pelo binômio Oncidium macropetalum Lindl., e está ilustrada, com este nome, em Cogniaux (1904-1906 - tab. 74, fig I) e Hoehne (1910 - tab. 56, fig 1). Caracteriza-se por ser epífita, com flores predominantemente amarelas, relativamente pequenas, em panículas pauciramosas. Ocorre no Paraguai e no Brasil (PA, GO, DF, MT, MS, MG e SP), normalmente associada a florestas decíduas ou semidecíduas. No Morro Santa Cruz foi coletada em uma altitude de $650 \mathrm{~m}$.
3. Aspidogyne longicornu (Cogn.) Garay, Bradea 2(28): 202. 1977 三 Physurus longicornu Cogn., Bull. Soc. Bot. Roy Belg. 43: 298. 1906 ” Erythrodes longicornu (Cogn.) Ames, Orchid. 5: 28. 1915.

= Physurus longicalcaratus Schltr., Anexos Mem. Inst. Butantan, Secc. Bot. 1: 35. 1922.

Terrícola. Caule cilíndrico, não intumescido em pseudobulbo, áfilo e prostrado na porção basal, folioso e ascendente na porção apical, a parte prostrada radicífera e semelhante a um rizoma; parte ereta 30-40 cm compr., ca. 0,7 cm larg. Folhas 11-12 cm compr., 3-3,5 cm larg., alternas, membranáceas, oblongas, pecioladas, base em bainha amplexicaule, com 3-4 nervuras acródromas. Inflorescência $15-16 \mathrm{~cm}$ compr., terminal, em racemo. Flores brancas com ápice das sépalas verde, calcaradas; sépalas ca. $6 \mathrm{~mm}$ compr., $2 \mathrm{~mm}$ larg., herbáceas, a dorsal largo-lanceolada, côncava, as laterais triangular-lanceoladas, não decurrentes no ovário; pétalas ca. $5 \mathrm{~mm}$ compr., $3 \mathrm{~mm}$ larg., brancas, inteiras, linear-lanceoladas; pedicelo + ovário ca. $16 \mathrm{~mm}$ compr., $2 \mathrm{~mm}$ larg.; labelo ca. $3 \mathrm{~mm}$ larg., âmbito oval-oblongo, ápice recurvado, base prolongada em calcar com ca. $22 \mathrm{~mm}$ compr., 1 mm larg.; ginostêmio ca. 4 mm compr., 1 mm larg.; polínias sécteis. Frutos não vistos.

Material examinado: BRASIL. MAto GRosso do SuL: Corumbá, Morro Santa Cruz, 1-X-1999, fl., fr., D.P. Rodriguez 13 (COR, SP).

Planta terrícola, caracterizada pela base do caule geralmente prostrada e radicífera, e parte apical ereta, folhas membranáceas, com nervação acródroma, flores com calcar desenvolvido na base do labelo e polínias sécteis. Encontrada, no Morro Santa Cruz, em mata fechada, úmida, em local alagadiço, à beira de córrego, a $220 \mathrm{~m}$ de altitude. No Brasil, ocorre nos Estados do AM, MT, SP (Pabst \& Dungs 1975) e MS. Ilustração da espécie é encontrada em Hoehne (1945 tab. 188), sob o nome Physurus longicalcaratus Schltr.

4. Campylocentrum hasslerianum Hoehne, Arq. Bot. Estado São Paulo, nova série 1(1): 23. 1938.

Figuras 5-7

Epífita (holoepífita), monopodial; raízes adventícias, cilíndricas, nos nós do caule. Caule 10$13 \mathrm{~cm}$ compr., cilíndrico. Folhas 5-5,5 cm compr., ca. $0,8 \mathrm{~cm}$ larg., dísticas, lanceoladas, subcoriáceas, margem lisa e plana, ápice fortemente assimétrico; base em bainha amplexicaule, bainha ca. 1,4 cm 


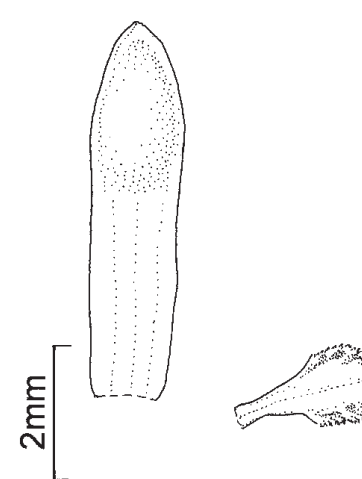

3
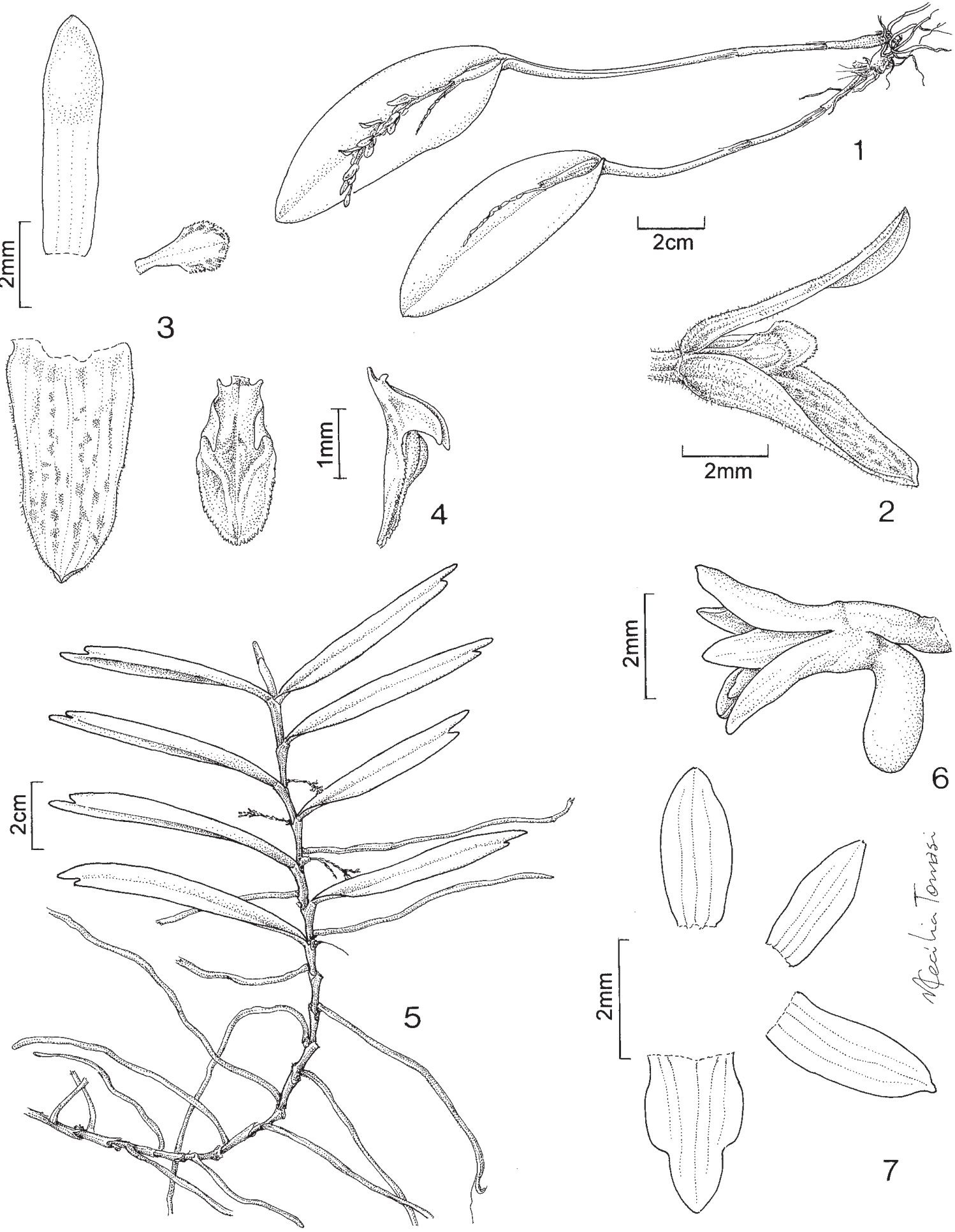

Figuras 1-7. Espécies de Orchidaceae do Morro Santa Cruz. 1-4. Acianthera pubescens (Lindl.) Pridgeon \& M.W. Chase. 1. Aspecto geral da planta florida. 2. Flor em vista lateral. 3. Peças do perianto distendidas. 4. Labelo em vista lateral. Figuras 5-7. Campylocentrum hasslerianum Barb. Rodr. 5. Aspecto geral da planta florida. 6. Flor em vista lateral. 7. Peças do perianto distendidas.

Figures 1-7. Species of Orchidaceae from "Morro Santa Cruz". 1-4. Acianthera pubescens (Lindl.) Pridgeon \& M.W. Chase. 1. Habit of a flowered plant. 2. Flower, side view. 3. Perianth, spread. 4. Lip, lateral view. 5-7. Campylocentrum hasslerianum Barb. Rodr. 5. Habit of a flowered plant. 6. Flower, side view. 7. Perianth, spread. 
compr. Inflorescência 2-3 cm compr., axilar, em racemo, solitária ou aos pares. Flores brancas; pedicelo + ovário ca. 1,5 mm compr.; sépala dorsal ca. 3,2 mm compr., 1,5 mm larg., elíptica, ápice obtuso; sépalas laterais ca. $3 \mathrm{~mm}$ compr., 1,5 mm larg., oblongolanceoladas, ápice sub-acuminado, ligeiramente assimétrico; pétalas ca. $3 \mathrm{~mm}$ compr., $1 \mathrm{~mm}$ larg., oblongo-lanceoladas, ápice obtuso; labelo ca. $2 \mathrm{~mm}$ compr., $1 \mathrm{~mm}$ larg., trilobado, base prolongada em calcar obtuso, genuflexo, lobos laterais com ápice obtuso, envolvendo o ginostêmio, lobo central largamente triangular, ápice obtuso; calcar ca. $4 \mathrm{~mm}$ compr.; polínias 2, cartilaginosas, dotadas de estipe e viscídio. Frutos não vistos.

Material examinado: BRASIL. Mato Grosso do Sul: Corumbá, Morro Santa Cruz, Mineração Corumbaense, 19²4'49"S, 59²2'47'W, 23-VII1999, fl., D.P. Rodriguez 8 (COR, SP).

Caracteriza-se pelo crescimento monopodial, folhas dísticas com ápice fortemente assimétrico e flores com calcar obtuso e genuflexo formado na base do labelo. Encontrada sobre árvore a 2-3 m de altura, em altitude de $670 \mathrm{~m}$. Espécie originalmente descrita a partir de material proveniente do Paraguai (Hoehne 1938), sendo, aqui, citada pela primeira vez para o Brasil.

5. Cattleya nobilior Rchb. f., Ill. Hort. 30: 73. 1883.

Epífita (holoepífita) ou rupícola, simpodial; raízes cilíndricas, nascendo nos nós do rizoma. Rizoma cilíndrico, esverdeado, alongado; cauloma 4-10,5 cm compr., 2-3 cm larg., intumescido em pseudobulbo, ereto, estreitamente elipsóide, 2-foliado, sulcado quando velho. Folhas 7-10,8 cm compr., 3-5 cm larg., coriáceo-carnosas, oblongas a elípticas. Inflorescência 14-19 cm compr., em racemo, terminal, 2-3-flora. Flores grandes, predominantemente róseo-lilás; pedicelo + ovário 3-4 cm compr., ca. $2 \mathrm{~mm}$ diâm.; sépalas subiguais, oblongas, a dorsal ca. 4,6 cm compr., 1,4 cm larg., as laterais ca. 4,2-5,5 cm compr., 1,3-1,5 cm larg., ligeiramente encurvadas; pétalas ca. 2,5 cm compr., 2,2 cm larg., obovado-rombóides, ápice apiculado; labelo ca. $3,8 \mathrm{~cm}$ compr., $3,4 \mathrm{~cm}$ larg., trilobado, lobo central, ca. $2 \mathrm{~cm}$ compr., $3,6 \mathrm{~cm}$ larg., largamente reniforme, ápice profundamente emarginado, margem ondulada, lobos laterais ca. $1,9 \mathrm{~cm}$ compr., semi-circulares a subtriangularovados, envolvendo parcialmente o ginostêmio, disco multicostado, ligeiramente amarelado com estrias lilás; ginostêmio ca. 26 mm compr., 6 mm larg., lilás; polínias 4, ceróides, com caudículas. Frutos não vistos.
Material examinado: BRASIL. MATo GRosso do SuL: Corumbá, Morro Santa Cruz, 13-X-1999, fl., fr., D.P. Rodriguez 15 (COR).

Material adicional examinado: BRASIL. GoIÁs: Iporá, em direção a Fazenda Nova, 16-XI-1998, fl., O. Gomes s.n. (SP332147). Mato Grosso: Correntes, XII-1918, fl., F.C. Hoehne s.n. (SP2609). Mato Grosso do Sul: Corumbá, IX-1914, fl., F.C. Hoehne 38 (SP).

Caracteriza-se pelas flores vistosas, grandes, de coloração róseo-lilás, pseudobulbos estreitamente elipsóides, bifoliados no ápice, inflorescência em racemo, pauciflora, terminal. Encontrada a $920 \mathrm{~m}$ de altitude sobre paredão rochoso. Ocorre no Brasil, nos Estados do MT, MS, TO, GO e DF, além do Paraguai (Pabst \& Dungs 1975) e Bolívia (Dodson \& Vásquez 1989a). Pela beleza de suas flores a espécie está amplamente ilustrada na literatura, podendo-se citar as obras de Linden (1885 - tab. 5 representando a variedade hugueneryi, uma variante de colorido), Hoehne (1910 - tab. 25), Withner (1988 - pág. 100) e Dodson \& Vasquez (1989 - tab. 208). Hoehne (1912) já indicara a ocorrência desta espécie na região de Coxim (MS) e Pott \& Pott (1994) citaram-na para o pantanal sul-mato-grossense.

6. Cyrtopodium virescens Rchb.f. \& Warm., Otia Bot. Hamburg. 2: 89. 1881.

Terrícola, cespitosa; raízes cilíndricas, fasciculadas. Rizoma inconspícuo; cauloma intumescido em pseudobulbo, 17-18 cm compr., 3-4 $\mathrm{cm}$ larg., fusiforme, homoblástico, envolvido por bainhas escariosas. Folhas 50-60 cm compr., 1,5-2 cm larg., subcoriáceas, com várias nervuras paralelas proeminentes, verdes, concolores. Inflorescência ca. $95 \mathrm{~cm}$ compr., em panícula, lateral, pedúnculo e ramos com brácteas verde-limão, maculadas de castanho. Flores verde-amareladas com máculas castanhas, destituídas de calcar; pedicelo + ovário ca. 2,6 cm compr., $2 \mathrm{~mm}$ larg.; sépalas ca. 1,9 cm compr., 0,9 cm larg., oblongas, margens onduladas; pétalas ca. 1,6 cm compr., 1,1 cm larg., obovadas; labelo ca. 1,3 cm compr., 1,6 cm larg., articulado com o pé do ginostêmio, trilobado, lobos laterais ca. $5 \mathrm{~mm}$ compr., $7 \mathrm{~mm}$ larg., eretos, lobo central ca. 5 mm larg.; ginostêmio ca. 10 mm compr., 3 mm larg., verde; polínias 2, cartilaginosas, dotadas de estipe e viscídio. Frutos não vistos.

Material examinado: BRASIL. Mato Grosso do Sul: Corumbá, Morro Santa Cruz, Mineração 
Corumbaense, 30-VII-1999, fl., D.P. Rodriguez 12 (COR, SP); Ladário, Fazenda São Sebastião do Carandá, 10-X-2001, fl., G.A. Damasceno Junior et al. 2783 (COR).

Caracterizada por ser terrícola, com inflorescência em panícula de ca. $95 \mathrm{~cm}$ alt., pedúnculo e ramos dotados de brácteas verde-limão, com máculas castanhas, flores com as sépalas de margem fortemente ondulada e maculadas de castanho. Encontrada em mata aberta, a $820 \mathrm{~m}$ de altitude e em áreas de bancada laterítica no pediplano da morrarria (150 a $200 \mathrm{~m})$. Ocorre, no Brasil, nos Estados de DF, GO, MG, MS e MT, além do Paraguai e Bolívia (Bianchetti \& Batista 2004). Ilustrações em Hoehne (1942 - tab. 6, fig. 2), Sprunger (1986 - tab. 7396) e Bianchetti \& Batista (2004 - figs. 10.1 I-K, 10.3 H). A espécie rambém foi citada para o pantanal sul-mato-grossense por Pott \& Pott (1994).

7. Encyclia conchaechila (Barb. Rodr.) Porto \& Brade, Rodriguésia 1(2): 28. 1935 三 Epidendrum conchaechilum Barb. Rodr., Gen. Sp. Orchid. 1: 53. 1877.

= Encyclia linearifolioides (Krzl.) Hoehne, Arq. Bot. Est. S. Paulo n.s. 1(1): 19. 1938.

Figuras 8-10

Epífita (holoepífita); raízes cilíndricas, nos nós do rizoma. Rizoma inconspícuo; cauloma intumescido em pseudobulbo, 3-3,5 cm compr., 1,5-2 cm larg., periforme-cônico, verde, 2-foliado no ápice. Folhas 20-30 cm compr., 1-1,5 cm larg., lanceoladas, coriáceas. Inflorescência ca. $30 \mathrm{~cm}$ alt., em panícula, às vezes em racemo, terminal, ereta, 4-20-flora. Flores com sépalas e pétalas de cor creme-esverdeada até mostarda e labelo branco; sépalas ca. $20 \mathrm{~mm}$ compr., $4 \mathrm{~mm}$ larg., lanceoladas; pétalas ca. $19 \mathrm{~mm}$ compr., $4 \mathrm{~mm}$ larg., lanceoladas; labelo ca. $10 \mathrm{~mm}$ compr., 9 $\mathrm{mm}$ larg., branco, trilobado, lobos laterais ca. $11 \mathrm{~mm}$ compr., $3 \mathrm{~mm}$ larg., triangular-oblongos, encurvados, abraçando o ginostêmio, lobo central ca. $3 \mathrm{~mm}$ larg., ovado-suborbicular, coberto por numerosas lamelas longitudinais; ginostêmio ca. $8 \mathrm{~mm}$ compr., $2 \mathrm{~mm}$ larg., verde, base não formando mento com as sépalas laterais; polínias 4, ceróides, dotadas apenas de caudículas. Frutos não vistos.

Material examinado: BRASIL. Mato Grosso do SuL: Corumbá, Morro Santa Cruz, 23-IX-1994, fl., M.A.C. Chaparro et al. 6 (COR, CPAP); idem, 30-VII-1999, fl., D.P. Rodriguez 9 (COR, SP).
Caracterizada por possuir perfume intenso, flores com sépalas e pétalas de cor creme-esverdeada até mostarda e labelo branco com lamelas longitudinais que se estendem desde a base até o meio do lobo central. Encontrada em altitudes de $750 \mathrm{~m}$ ou inferiores a 420-620 m, tanto em árvores a 2-3 m de altura em mata úmida e com pouca luminosidade, como a pleno sol, sobre árvores altas. No Brasil, ocorre nos Estados de RR, AM, PA, TO, GO, DF, MT, MS, MG, SP e PR. Também encontrada na Venezuela, Peru, Bolívia, Argentina e Paraguai.

8. Epidendrum coronatum Ruiz \& Pavón, Syst. Veg. Fl. Peruv. Chil. 1: 142. 1798.

Epífita (holoepífita), cespitosa; raízes cilíndricas, fasciculadas. Rizoma inconspícuo; cauloma 50$62 \mathrm{~cm}$ compr., não intumescido em pseudobulbo, multifoliado, cilíndrico. Folhas dísticas, lâminas 13-14 cm compr., 3-4 cm larg., elíptico-lanceoladas, subcoriáceas, base em bainha amplexicaule, bainha 2,9-7 cm compr. Inflorescência terminal, em racemo, 15-30-flora com duas espatas pequenas na base. Flores castanho-esverdeadas; pedicelo + ovário ca. 2,1 cm compr., $3 \mathrm{~mm}$ larg., ovário não articulado com o pedicelo; sépalas livres entre si, ca. 1,8 cm compr., 0,7 $\mathrm{cm}$ larg., estreitamente obovadas a oblongo-obovadas, carnosas, rígidas, ápice apiculado, as laterais ligeiramente assimétricas; pétalas ca. 1,7 cm compr., 0,4 cm larg., espatuladas, herbáceo-subcoriáceas, ápice curtamente acuminado, base longamente atenuada; labelo ca. 1,5 cm compr., 1,6 cm larg., trilobado, coriáceo, amarelo-esverdeado, base unguiculada, com margens adnadas às margens ventrais do ginostêmio, lobos laterais assimetricamente flabelados, lobo central bilobulado, lóbulos estreitamente obovadoespatulados, ligeiramente assimétricos; ginostêmio clavado, creme-esverdeado, ca. $13 \mathrm{~mm}$ compr., 0,5 mm larg.; polínias 4, ceróides, dotadas de caudícula. Frutos não vistos.

Material examinado: BRASIL. MAto GRosso do SUL: Corumbá, Morro Santa Cruz, 23-IX-1994, fl., M.A.C. Chaparro et al. 8 (COR, CPAP); idem, 23-IX-1994, fl., M.A.C. Chaparro \& I.M. Bortolotto s.n. (COR3490, SP271207); idem, 30-IV-1999, fl., D.P. Rodriguez 11 (COR, CPAP); idem, 24-X-2000, fl., G.A. Damasceno Junior \& D.P. Rodriguez 1986 (CGMS, SP); idem, cultivada na Seção de Orquidário do Instituto de Botânica, 11-XI-2005, fl., F. Barros s.n. (SP409466).

Caracterizada por possuir folhas dísticas, caule não espessado em pseudobulbo, sépalas carnosas, 
rígidas, de cor castanho-esverdeada e unguículo do labelo concrescido com as bordas do ginostêmio. Foi encontrada em mata fechada e com pouca luminosidade a $740 \mathrm{~m}$ e, também, em altitudes inferiores a 420-640 $\mathrm{m}$, em árvores, a 1,5-3 m de altura. Ocorre desde o México até o Peru e Bolívia (Dodson \& Vásquez 1989b, Bennett \& Christenson 1993) e também no Brasil (AM, PA, MT e MS). Ilustrações em Dusterville \& Garay (1965 - pág. 99), Dodson \& Dodson (1989 - tab. 465) e Sprunger (1996 - pág. 283).

9. Epidendrum densiflorum Hook., Bot. Mag. 66: t. 3791. 1840.

Figura 11-13

Epífita (holoepífita), simpodial. Rizoma curto; cauloma 13-100 cm compr., 0,2-2,3 cm diâm., não intumescido em pseudobulbo, multifoliado, cilíndrico, sem ramificações laterais, recoberto pelas bainhas das folhas. Folhas dísticas; bainhas cilíndricas, imbricadas; lâminas 5-23 cm compr., 1,2-5 cm larg., elípticas a estreitamente-obovadas, ápice agudo. Inflorescência 13-40 cm compr., terminal, em panícula, nutante, densamente multiflora; base do pedúnculo coberta por 2 espatas de 2,5-7 cm compr.; brácteas lanceoladas, 0,1-6,9cm compr., ápice acuminado. Flores ressupinadas, glabras, 1-3 cm diâm.; pedicelo + ovário 1-3,5 cm compr., ovário não articulado com o pedicelo; sépalas livres entre si, patentes, verdes a creme-esverdeadas, a dorsal 10-15 mm compr., 2-4 mm larg., estreitamente oblanceolada a estreitamente oblongo-oblanceolada, ápice agudo a acuminado, as laterais 11-14 mm compr., 2,5-5 mm larg., estreitamente obovadas a estreitamente oblanceoladas, levemente assimétricas, ápice acuminado; pétalas 11-14 mm compr., 1-2 mm larg., linear-espatuladas, herbáceas, ápice obtuso ou agudo; labelo trilobado, branco a branco-esverdeado, base com unguículo adnado às margens laterais do ginostêmio até o ápice deste, lâmina 6-9 mm compr., 9-11 mm larg., 3-lobada, âmbito suborbicular a largamente obovado, lobos laterais 3-4 mm compr., 4-8 mm larg., flabeliformes ou sub-flabeliformes, lobo central 2-lobulado, lóbulos 2-3 mm compr., 1,5-3 mm larg., oblongos, ligeiramente falcados, divergentes, ápice agudo, disco com 1 lamela central e dois calos arredondados na base prolongados em lamelas longitudinais; ginostêmio branco, 8-9 mm compr., clavado; polínias 4, ceróides, dotadas de caudícula. Frutos não vistos.

Material examinado: BRASIL. Mato Grosso do Sul: Corumbá, Morro Santa Cruz, Mineração
Corumbaense, cultivada na Seção de Orquidário do Instituto de Botânica, 4-XI-2002, fl., F. Barros s.n. (SP409468); idem, 24-VI-2002, fl., D.P. Rodriguez 64 (COR).

Material adicional examinado: BRASIL. S̃̃o PAULO: Amparo, 18-VII-1927, fl., P. Recch s.n. (SP29321); Cananéia, Ilha do Cardoso, 18-VIII-2004, fl., F. Barros et al. 3085 (SP); Ipanema, 17-X-1932, fl., F.C. Hoehne s.n. (SP29825); São Paulo, Serra da Cantareira, 15Xl-1919, fl., F.C. Hoehne s.n. (SP3482); Teodoro Sampaio, Parque Estadual do Morro do Diabo, Córrego da Onça, 23-Vl-1994, fl., O.T. Aguiar 472 (SP); idem, 19-VII-1989, P. Martuscelli s.n. (SP315021).

Caracteriza-se pelas plantas altas, chegando a $1 \mathrm{~m}$ alt., caule não espessado em pseudobulbo, folhas dísticas, inflorescência em panículas amplas, emergindo de duas pequenas espatas basais, flores com sépalas e pétalas verdes a creme-esverdeadas e labelo branco-esverdeado, perfumadas. Ocorre por toda a América tropical (Dunsterville \& Garay 1961). No Brasil foi encontrada nos Estados de AM, PA, RO, MT, BA, GO, DF, MG, ES, RJ, SP, PR, SC e RS (Pabst \& Dungs 1975) e MS. No Morro Santa Cruz foi coletada como epífita em Floresta Estacional Semidecidual, a cerca de $750 \mathrm{~m}$ de altitude.

10. Epistephium sclerophyllum Lindl., Gen. Sp. Orch. Pl.p. 433. 1840.

Terrícola, ereta. Caule cilíndrico, muitas vezes ramificado, não intumescido em pseudobulbo, $(0,6-$ ) $, 8-1,2 \mathrm{~m}$ alt. Folhas (3,4-)4,5-11 cm compr., (1,7-)3$6,7 \mathrm{~cm}$ larg., coriáceas, rígidas, largamente lanceoladas, oval-lanceoladas, elípticas até largamente ovadas, sésseis, as do centro do caule maiores, ápice agudo a acuminado, geralmente dotado de um apículo, base ligeiramente amplexicaule, 7 nervuras longitudinais mais destacadas, interligadas por nervuras reticuladas. Inflorescência (9-)24-42 cm compr., terminal, em racemo; brácteas florais escamiformes, ovaltriangulares. Flores predominantemente róseolilás, destituídas de calcar; sépalas membranáceas, a dorsal (3,6-)4-5,6 cm compr., (0,5-)0,8-1 cm larg., estreitamente obovada, ápice acuminado, as laterais (3,4-)4-5,3 cm compr., (0,5)0,9-1,1 cm larg., estreitamente oboval-lanceoladas, não decurrentes no ovário; pétalas (3,7-)4,2-5,7 cm compr., 1-1,6 cm larg., estreitamente obovais a estreitamente obovallanceoladas; labelo (3,8-)4,5-5,5 cm compr., (2,3-)3- 


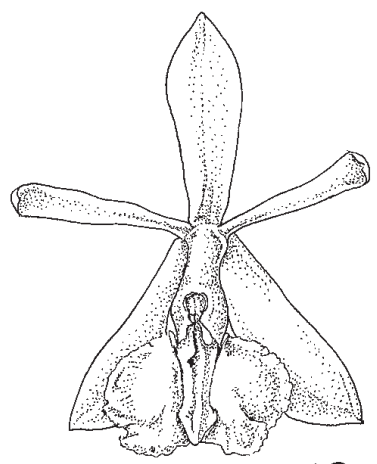

12

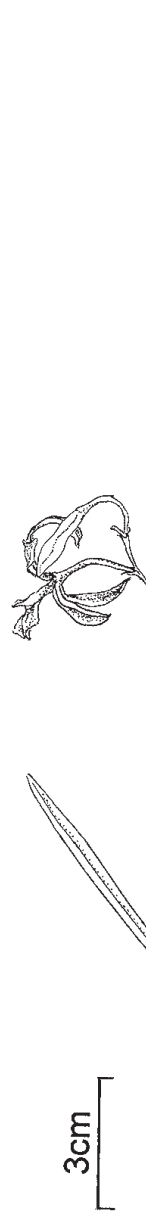

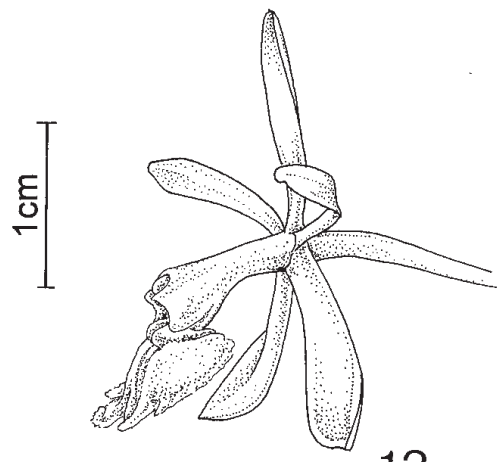

13
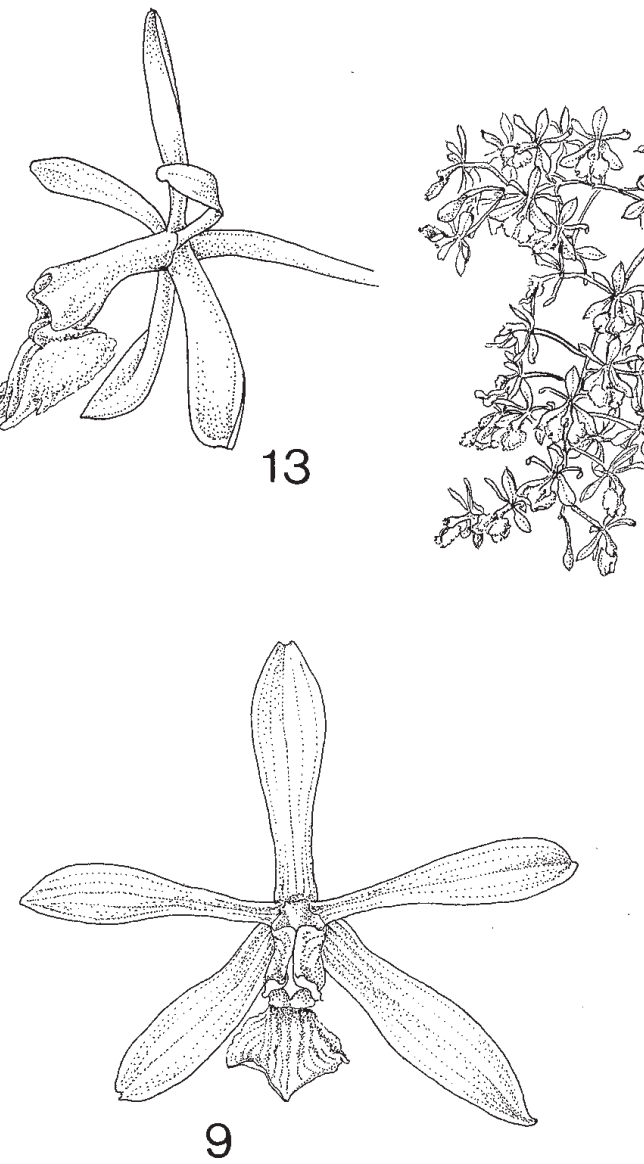

9
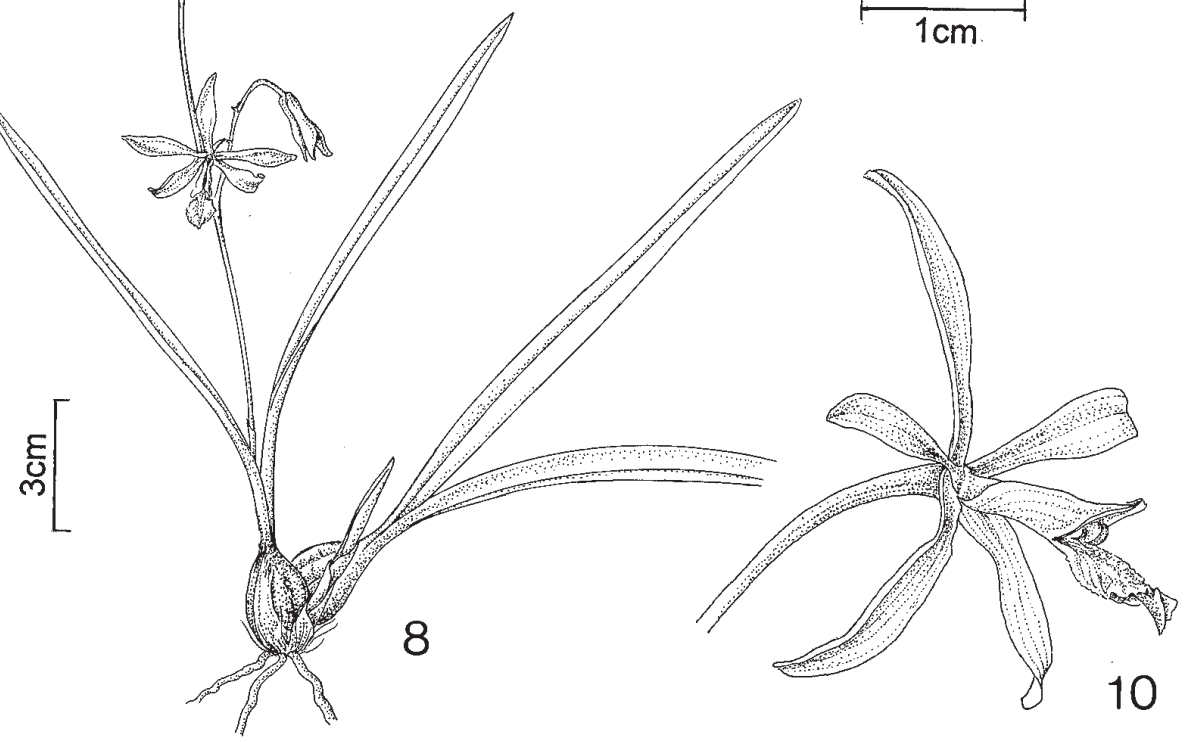

10

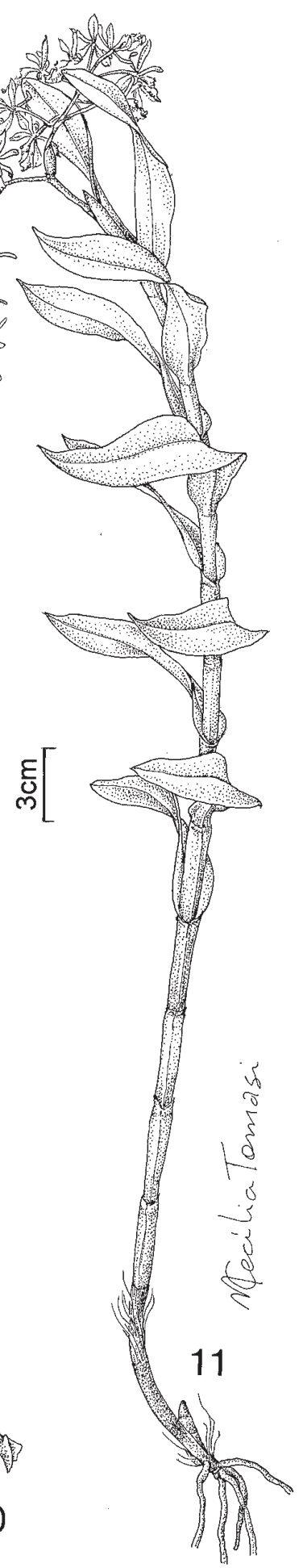

Figuras 8-13. Espécies de Orchidaceae do Morro Santa Cruz. 8-10. Encyclia conchaechila (Barb. Rodr.) Porto \& Brade. 8. Aspecto geral da planta florida. 9. Flor em vista lateral. 10. Flor em vista frontal. 11-13. Epidendrum densiflorum Hook. 11. Aspecto geral da planta florida. 12. Flor em vista frontal. 13. Flor em vista lateral.

Figues 8-13. Species of Orchidaceae from "Morro Santa Cruz". 8-10. Encyclia conchaechila (Barb. Rodr.) Porto \& Brade. 8. Habit of a flowered plant. 9. Flower, side view. 10. Flower, frontal view. 11-13. Epidendrum densiflorum Hook. 11. Habit of a flowered plant. 12. Flower, frontal view. 13. Flower, side view. 
$3,5 \mathrm{~cm}$ larg., inteiro a sub-trilobado, âmbito oboval, ápice emarginado, base curtamente unguiculada, unguículo adnado à base do ginostêmio, margens mais ou menos encrespadas, disco róseo-violáceo, dotado no centro de uma série longitudinal de barbelas simples ou ramificadas; ginostêmio (2,7)3,5 cm compr.; ovário com um calículo distinto no ápice; grãos de pólen laxamente unidos, não formando polínias distintas. Frutos não vistos.

Material examinado: BRASIL. Mato Grosso do Sul: Corumbá, Morro Santa Cruz, Mineração Corumbaense, $19^{\circ} 13^{\prime} 8,4^{\prime \prime}$ 'S , 57³5'1,'”'W, 21-II-2005, fl., G.A. Damasceno Junior et al. 3433 (COR, SP).

Material adicional examinado: BRASIL. GoIÁs: Rodovia Goiânia-São Paulo, Jardim Goiás, 1-III-1969, fl., J.A. Rizzo \& A. Barbosa 3789 (UFG); Goiânia, Estrada para o Seminário Santa Cruz, s.d., fl., J.A. Rizzo 3534 (SP). Minas Gerais: Grão Mogol, 3-IV1980, fl., F. Barros 50 (SP). SÃo PAulo: Pedregulho, Parque Estadual Furnas do Bom Jesus, Cerrado Santa Luzia, 5-V-1995, fl., J.R. Guillaumont \& E.E. Macedo 69 (SPSF); Botucatu, 16-II-1920, fl., G. Gehrt 3650 (SP); Mogi Guaçú, 3-II-1955, fl., O. Handro 446 (SP).

Caracteriza-se por ser terrícola, com folhas rijas e multinervulosas, as nervuras reticuladas, flores vistosas, com calículo no ápice do ovário e pólen não formando polínias distintas. Amplamente distribuída por quase todas as formações campestres do Brasil (AM, PA, BA, GO, DF, MT, MS, MG, SP, PR), ocorrendo também no Paraguai, Peru e Bolívia (Pabst \& Dungs 1975). Epistephium sclerophyllum é muito variável no porte e no tamanho das flores de modo que talvez represente um complexo de espécies fortemente relacionadas. Hoehne (1945) já havia destacado sua extrema variabilidade. O material estudado do Morro Santa Cruz possui flores bastante reduzidas. Sua ocorrência no Mato Grosso do Sul já havia sido apontada por Bortolotto et al. (1999), para o Morro do Urucum, Município de Corumbá. Ilustração em Hoehne (1945, tab. 37).

11. Habenaria juruenensis Hoehne, Relat. Comm. Lin. Telegr., Bot. 5: 32, t. 85, fig. II. 1915.

Terrícola, $20-40 \mathrm{~cm}$ alt. quando florida. Caule ereto, não intumescido em pseudobulbo, cilíndrico, verde-glauco. Folhas 4-6 cm compr., 1-2 cm larg., membranáceas, sésseis, suberetas, oblongolanceoladas, decrescendo em direção ao ápice do caule, ápice agudo a obtuso, base invaginante, frouxamente amplexicaule, face abaxial mais ou menos carenada. Inflorescência 4-10 cm compr., em racemo, 5-8-flora; brácteas florais ca. $2 \mathrm{~cm}$ compr., $0,8 \mathrm{~cm}$ larg., amplectivas, frouxas, ovado-lanceoladas, decrescendo em direção ao ápice, ápice acuminado. Flores brancas, sub-carnosas, calcaradas; pedicelo + ovário ca. $2 \mathrm{~cm}$ compr.; sépalas côncavas, herbácedas, ápice obtuso, curtamente apiculado, a dorsal 6-7 mm compr., ca. $5,5 \mathrm{~mm}$ larg., ovada, com face abaxial carenada, as laterais ca. $7 \mathrm{~mm}$ compr., $3,5 \mathrm{~mm}$ larg., ovadotriangulares, oblíquas, patentes, não decurrentes no ovário; pétalas bipartidas, segmento anterior ca. $5 \mathrm{~mm}$ compr., 0,5 mm larg., linear, ligeiramente encurvado, ápice obtuso, segmento posterior ca. $6 \mathrm{~mm}$ compr., 2 $\mathrm{mm}$ larg., oblongo-ligulado, ligeiramente assimétrico, ápice obtuso, margem superior aglutinada à margem da sépala dorsal; labelo ca. $5 \mathrm{~mm}$ compr., $1 \mathrm{~mm}$ larg., tripartido, segmentos laterais linear-ligulados, ápice obtuso, segmento mediano ca. $7 \mathrm{~mm}$ compr., $1,3 \mathrm{~mm}$ larg., linear-ligulado, ápice obtuso; calcar ca. $2 \mathrm{~cm}$ compr., 1 mm diâm., filiforme, pendente, encurvado, ápice subagudo, escondido entre as brácteas; antera fortemente presa ao ginostêmio, não articulada, tecas separadas; processos estigmatíferos ca. 1,5 mm compr.; polínias sécteis, com caudícula e viscídio. Frutos não vistos.

Material examinado: BRASIL. MATo GRosso do SuL: Corumbá, Morro do Urucum, 19-I-1996, fl., I.M. Bortolotto et al. 175 (COR, SP).

Material adicional examinado: BRASIL. Mato Grosso: Campos úmidos do Juruena, quase nas cabeceiras do rio Juruena, XII-1911, fl., F.C. Hoehne C.L.T.E.M.G.A 5335 (SP28926 - isótipo).

Habenaria juruenensis pertence ao grupo de espécies que Hoehne (1940) denominou "Agrupamento GUILLEMINII", caracterizado pelas plantas pequenas, com folhas predominantemente na porção basal do caule, pouco patentes e carnosas. Habenaria juruenensis caracteriza-se, ainda, pelas folhas com base invaginante e infundibulada, brácteas florais tão longas quanto pedicelo + ovário, flores brancas, com calcar longo e cilíndrico, pelos segmentos posteriores das pétalas tão longos, ou quase tão longos, quanto os anteriores. Espécie conhecida, até hoje, apenas do Estado do Mato Grosso e do Distrito Federal, Brasil (Pabst \& Dungs 1975, Batista \& Bianchetti 2001); encontrada, agora, também no Mato Grosso do Sul. Ilustração em Hoehne (1915 - tab. 85, fig. 2; 1940 tab. 120, fig. 2). 
12. Habenaria polycarpa Hoehne, Comm. Lin. Telegr., Bot 5: 34, t. 86. 1915.

Terrícola. Caule 50,5-80 cm alt., ca. 5 mm diâm., ereto, cilíndrico, não intumescido em pseudobulbo, folioso. Folhas membranáceas, sésseis, ereto-patentes, ápice agudo a acuminado, base em bainha invaginante; limbo 12-17 cm compr., 3,9-6,5 cm larg. nas folhas do meio do caule, oval a elíptico, tenuemente reticulado, decrescendo gradativamente em direção ao ápice do caule. Inflorescência 18,5-21 cm compr., em racemo, ereta, pluriflora; brácteas florais 2,5-4 cm compr., 0,5-1 cm larg., eretas, geralmente mais longas que pedicelo + ovário, ápice longamente acuminado. Flores verde-claras, herbáceas, calcaradas; pedicelo + ovário ca. $2 \mathrm{~cm}$ compr.; sépala dorsal 8-11 mm compr., 7-8,5 mm larg., ovada, cuculada, ápice obtuso, as laterais 9-12 mm compr., 3,5-4,5 mm larg., oblongo-obovadas, levemente oblíquas, reflexas, ápice obtuso, não decurrentes no ovário; pétalas inteiras, 7-11 mm compr., 1,5-1,8 mm larg., linear-falcadas, alargando gradativamente em direção ao ápice, ápice obtuso, próximo à base dotadas de um dente filiforme-assovelado de 1-2 mm compr., ápice agudo; labelo pendente, trilobado, lobos laterais filiformes, patentes, lobo central 10-13 mm compr., ca. $1 \mathrm{~mm}$ larg., liguliforme; calcar 20-25 mm compr., cilíndrico, estreitando em direção ao ápice; antera fortemente presa ao ginostêmio, não articulada, tecas separadas; processos estigmatíferos ca. $2 \mathrm{~mm}$ compr.; polínias sécteis, com caudícula e viscídio. Frutos ca. $1,5 \mathrm{~cm}$ compr., fusiforme-elipsóides, 6-costados, ligeiramente encurvados.

Material examinado: BRASIL. MAto Grosso do SuL: Ladário, Morro Santa Cruz, Fazenda Paraíso, 28-V2001, fr., G.A. Damasceno Junior 2416 (CGMS); idem, 20-III-2003, fl., G.A. Damasceno Junior et al. 3143 (CGMS).

Material adicional examinado: BRASIL. MATO Grosso: São Lourenço, Maribondo, IV-1911, fl., F.C. Hoehne in Com. Rondon no 4094 (SP - isótipo).

Habenaria polycarpa pertence ao grupo denominado "Agrupamento LEPTOCERAS" por Hoehne (1940), e que se caracteriza pelas plantas relativamente altas, com várias folhas membranáceas, tenuemente reticuladas, dispostas por toda a extensão do caule, e pelas flores pequenas. Distingue-se da outra espécie ocorrente na região, pelas brácteas florais mais longas que pedicelo + ovário, flores verde-claras, pétalas alargadas em direção ao ápice e com um dente filiforme-assovelado na base, labelo com lobos laterais filiformes. Conhecida apenas do Brasil, nos Estados do Mato Grosso (Hoehne 1915) e Minas Gerais (Pabst \& Dungs 1975), agora encontrada também no Mato Grosso do Sul. Por se tratar de uma espécie típica do Brasil Central, a indicação de sua ocorrência em Pernambuco por Pabst \& Dungs (1975) parece pouco provável. Ilustração em Hoehne (1915 - tab. 86; 1940 - tab. 40).

13. Isochilus linearis (Jacq.) R. Br. in Aiton, Hort. Kew., ed. 2, 5: 209. 1813 E Epidendrum lineare Jacq., Enum. Syst. Pl.: 29. 1760.

$=$ Isochilus brasiliensis Schltr., Fedde Repert. Beih. 9: 80. 1921.

Figuras 14-15

Epífita (holoepífita), simpodial; raízes cilíndricas, muito engrossadas, fasciculadas. Rizoma inconspícuo; cauloma (14-)35-45 cm alt., ca. 0,1 cm diâm., não intumescido em pseudobulbo, delgado, ereto, multifoliado. Folhas 4,5-5 cm compr., ca. $0,3 \mathrm{~cm}$ larg., dísticas, linear-oblongas, delicadas, ápice assimétrico, base em bainha tubulosa, amplexicaule; bainhas ca. 1,6 cm compr. Inflorescência 2-3 cm alt., terminal, em racemo congesto, dotada de brácteas florais que encobrem o pedicelo e o ovário. Flores lilás a róseas; ovário não articulado com o pedicelo; sépalas coalescentes até cerca de $2 / 3$ do comprimento, formando um tubo com ca. $9 \mathrm{~mm}$ compr., $5 \mathrm{~mm}$ larg.; pétalas 6-8 mm compr., 1,5-2 mm larg., estreitamente lanceoladas, estreitamente oblongo-lanceoladas ou oblanceoladas, ápice agudo; labelo inteiro, ca. $8 \mathrm{~mm}$ compr., $1 \mathrm{~mm}$ larg., linear, ligeiramente alargado próximo à base, ápice agudo, face abaxial pubérula próximo à base; ginostêmio ca. $4 \mathrm{~mm}$ compr., base prolongada em um pé curto; polínias 4, ceróides, com caudículas. Frutos ca. $1 \mathrm{~cm}$ compr., $3 \mathrm{~mm}$ larg., oblongóides, sub-trígonos.

Material examinado: BRASIL. Mato Grosso do Sul: Corumbá, Morro da Mineração Corumbaense, 23-IX-1994, fr., M.A.C. Chaparro \& I.M. Bortolotto s.n. (COR3488, SP271206); Morro Santa Cruz, 23IV-1994, fr., M.A.C. Chaparro et al. 7 (COR, CPAP); idem, 30-VII-1999, fr., D.P. Rodriguez 10 (COR, SP).

Material adicional examinado: BRASIL. MInAs GeraIS: Poços de Caldas, Cascata da Luz, 24-III-1920, fl., fr., F.C. Hoehne s.n. (SP3825). Rio DE JANEIRO: Resende, Parque Nacional do Itatiaia, 23-VII-1966, fr., 


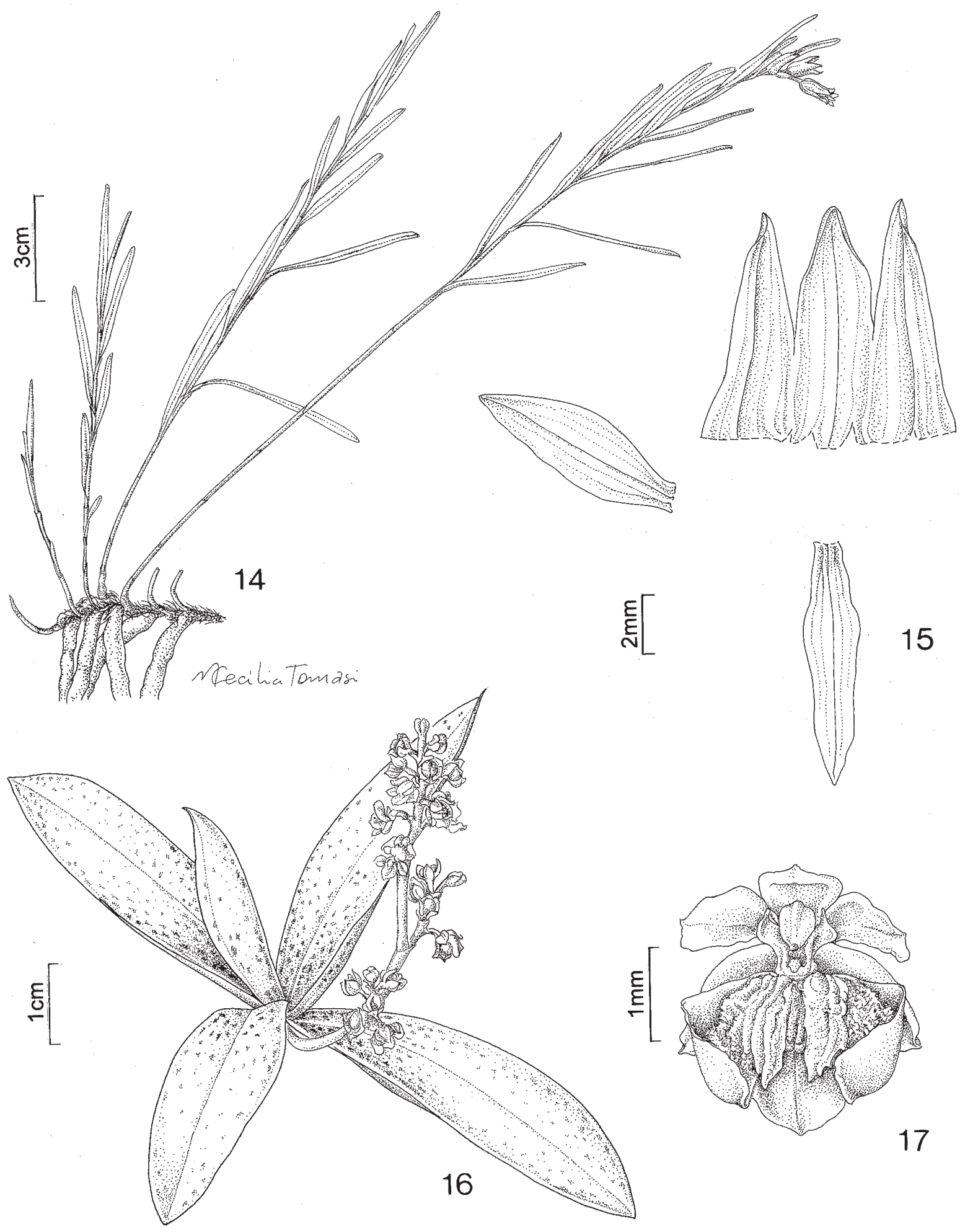

Figuras 14-17. Espécies de Orchidaceae do Morro Santa Cruz. 14-15. Isochilus linearis (Jacq.) R. Br. 14. Aspecto geral da planta florida. 15. Peças do perianto distendidas. 16-17. Lophiaris morenoi (Dodson \& Luer) Braem. 16. Aspecto geral da planta florida. 17. Flor em vista frontal.

Figures 14-17. Species of Orchidaceae from "Morro Santa Cruz". 14-15. Isochilus linearis (Jacq.) R. Br. 14. Habit of a flowered plant. 15. Perianth, spread. 16-17. Lophiaris morenoi (Dodson \& Luer) Braem. 16. Habit of a flowered plant. 17. Flower, frontal view. 
G. Eiten \& L.T. Eiten 7262 (SP). Rio Grande DO SUL: Porto Alegre, Morro da Glória, 9-IX-1932, fl., s. col . (SP50516). Santa CatARINA: Brusque, 29-V-1950, fl., R. Reitz 3569 (SP). São PaUlo: Cotia, cabeceiras do rio Cotia, 12-VI-1930, fl., fr., A. Gehrt s.n. (SP25330).

Caracterizada pelas raízes grossas, caules finos (ca. $1 \mathrm{~mm}$ diâm.), densamente cespitoso, com folhas dísticas, delicadas, linear-oblongas, inflorescência em racemo mais curto que as folhas, e flores tubulosas, lilases a róseas. Encontrada em árvore em pleno sol a $690 \mathrm{~m}$ de altitude ou mata fechada com pouca luminosidade e úmida a $720 \mathrm{~m}$ de altitude, em geral a 3-5 m de altura sobre o forófito. Apresenta ampla distribuição geográfica ocorrendo por toda a América tropical e subtropical, desde o México e Cuba até a Argentina e Paraguai (Pabst \& Dungs 1975). No Brasil, ocorre nos Estados de DF, MG, RJ, SP, PR, SC e RS (Pabst \& Dungs 1975) e MS

14. Lophiaris morenoi (Dodson \& Luer) Braem, Schlechteriana 4: 19. 1993 = Oncidium morenoi Dodson \& Luer, Selbyana 1: 44. 1976 三 Trichocentrum morenoi (Dodson \& Luer) M.W. Chase \& N.H. Williams, Lindleyana 16: 138. 2001.

Figuras 16-17

Epífita (holoepífita), simpodial; raízes cilíndricas, fasciculadas. Rizoma inconspícuo; cauloma ca. $4 \mathrm{~mm}$ compr., intumescido em pseudobulbo, cilíndricoovóide, 1-foliado. Folhas 3-6 cm compr., 1,5-2 cm larg., elípticas a oblongas, carnosas, sésseis, verdeescuras, com pontuações castanhas na face dorsal, ápice agudo, margem inteira, somente a nervura central saliente na face abaxial. Inflorescência 4-6 cm compr., em panícula, lateral. Flores predominantemente brancas; pedicelo + ovário ca. 1,5 mm compr.; sépalas ca. $2 \mathrm{~mm}$ compr., $2 \mathrm{~mm}$ larg., ovadas; pétalas ca. 2 $\mathrm{mm}$ compr., $1 \mathrm{~mm}$ larg., oblongas; labelo ca. $3 \mathrm{~mm}$ compr., 4,5 mm larg., trilobado, maior que as sépalas e pétalas, com duas calosidades amarelas no disco, lobos laterais obliquamente sub-retangulares, ca. 2,8 mm compr., 3,5 mm larg., ápice truncado, levemente irregular, lobo central semi-ovado, ca. 1,6 mm compr.; ginostêmio quase perpendicular ao ovário,ca. 1,1 mm compr., polínias 2, amarelas, cartilaginosas, dotadas de estipe e viscídio. Frutos não vistos.

Material examinado: BRASIL. MAto GRosso do SUL: Corumbá, Morro Santa Cruz, 1-X-1999, fl., D.P. Rodriguez 14 (COR, SP); idem, 3-XI-2000, fl., G.A. Damasceno Junior et al. 2031 (COR, SP).
Material adicional examinado: BRASIL. SEM LOCALIDADE: Cultivada na Seção de Orquidário do Instituto de Botânica (SP), sob n⿳0 14722 , doação de M.A. Campacci, fl., VI-2002, F. Barros s.n. (SP409467).

Caracterizada por apresentar pseudobulbos pequenos (ca. $4 \mathrm{~mm}$ compr.), 1-foliados, folhas carnosas, elípticas a oblongas, com 3-6 $\square$ 1,5-2 cm, inflorescência em panícula, com flores pequenas, predominantemente brancas. Encontrada sobre árvores a 3-4 m de altura a $620 \mathrm{~m}$ de altitude. Descrita originalmente para a Bolívia (Dodson \& Luer 1976), e hoje sua ocorrência é conhecida também para o Peru (Dodson \& Benett 1989) e Brasil (MT, MS, ES e SP).

15. Octomeria warmingii Rchb. f., Otia Bot. Hamburg.: 94. 1881.

= Octomeria iguapensis Schltr., Anexos Mem. Inst. Butantan, Secc. Bot. 55: 50. 1922.

= Octomeria oxychela Barb. Rodr., Gen. Sp. Orchid. 2: 99. 1882.

= Octomeria pinicola Barb. Rodr., Gen. Sp. Orchid. 2: 101.1882.

Figuras 18-21

Epífita (holoepífita), simpodial; raízes filiformes. Rizoma inconspícuo; cauloma 7,5-10 cm compr., ca. 1,5 mm larg., não intumescido em pseudobulbo, 1-foliado; bainhas persistentes, cobrindo total ou parcialmente o cauloma. Folhas 8-9 cm compr., 1-1,5 cm larg., estreitamente lanceoladas, carnosas. Inflorescência em fascículo, axilar, 3-6-flora; brácteas florais congestas, encobrindo pedicelo, ovário e a base da flor. Flores branco-amareladas, glabras; pedicelo + ovário ca. 2 mm compr., 1 mm larg., glabros; ovário articulado com o pedicelo; sépalas externamente glabras, a dorsal ca. $5 \mathrm{~mm}$ compr., $3 \mathrm{~mm}$ larg., estreitamente oblongo-oboval, as laterais ca. $5 \mathrm{~mm}$ compr., $3 \mathrm{~mm}$ larg., oblongo-ovais; pétalas ca. $4 \mathrm{~mm}$ compr., $3 \mathrm{~mm}$ larg., estreitamente oblongo-obovais; labelo ca. 3,5 mm compr., $2 \mathrm{~mm}$ larg., trilobado, lobos laterais suborbiculares, lobo central sub-retangular, ápice truncado a bidenticulado; ginostêmio encurvado; polínias 8 , ceróides, dotadas de caudículas muito pequenas. Frutos não vistos.

Material examinado: BRASIL. MAto GRosso do SuL: Corumbá, Morro Santa Cruz, 23-IX-1994, fl., M.A.C. Chaparro \& I.M. Bortolotto 10 (COR, CPAP, SP); idem, 4-VII-1998, fl., G.A. Damasceno Junior et al. 1190 (CGMS, SP); idem, 15-VIII-1998, M. Moraes et 
al. 4 (COR); idem, 20-I-1999, fl., fr., D.P. Rodriguez 3 (COR, SP); idem, 25-VI-1999, fl., fr., D.P. Rodriguez 7 (COR, SP).

Caracteriza-se pelos caules finos, folhas estreitamente-lanceoladas, inflorescência axilar em fascículo, flores branco-amareladas parcialmente encobertas por brácteas florais congestas, e ginostêmio com oito polínias. Coletada sobre árvore a 2-3 m de altura a $750 \mathrm{~m}$ de altitude em mata fechada com pouca luminosidade. No Brasil ocorre nos Estados do MS, MG, ES, RJ, SP, PR, SC e RS, e também na Argentina e Paraguai (Forster 2007). A revisão taxonômica das espécies com folhas planas e conduplicadas do gênero Octomeria (Forster 2007) mostrou que os nomes Octomeria iguapensis, Octomeria oxychela e Octomeria pinicola, comumente utilizados para identificação de espécies brasileiras, devem ser considerados sinônimos de $O$. warmingii .

16. Oeceoclades maculata (Lindl.) Lindl., Gen. Sp. Orchid. Pl.p. 237.1833 = Angraecum maculatum Lindl., Coll. Bot.: 15. 1821 E Eulophidium maculatum (Lindl.) Pfitzer, Entwurf. Anordn. Orch.: 87. 1887.

= Epidendrum connivens Vell., Fl. Flumin. 9: t. 44. 1831.

Terrícola. Rizoma pouco conspícuo; cauloma 1,5-3,5 cm compr., 0,7-1,7 cm larg., intumescido em pseudobulbo, heteroblástico, elipsóide a ovalado, ligeiramente compresso lateralmente, 1 -foliado. Folhas 10-29 cm compr., 2-4,8 cm larg., coriáceas, elípticas a estreitamente-obovadas, verde-escuras marmorizadas de verde-claro, ápice agudo, base atenuada. Inflorescência 15,5-39,7 cm compr., ereta, em racemo, raramente ramificada, lateral, 3-16-flora. Flores ressupinadas; pedicelo + ovário 9-15 mm compr., castanho-esverdeados; sépalas sub-coriáceas, côncavas, oblongo-obovadas, castanho-esverdeadas, a dorsal 8-13 mm compr., 2,2-3 mm larg., ápice mucronado a mucronulado, margem inteira, as laterais 7,5-12 mm compr., 2,2-3 mm larg., subfalcadas, ápice agudo a mucronado, margem inteira a ligeiramente erosa na região distal; pétalas 8-13 mm compr., 2-4 mm larg., subcoriáceas, elípticas a estreitamente espatuladas, assimétricas, castanho-esverdeadas, ápice mucronado, margem inteira a ligeiramente erosa na região distal; labelo 7-10 mm compr., 8-10 mm larg., panduriforme, lâmina distal flabeliforme, vinácea com ápice e uma faixa longitudinal brancos, margem ligeiramente ondulada, ápice emarginado-mucronado, disco com duas cristas ligeiramente tombadas para os lados; calcar 2,7-5,3 mm compr., claviforme, ligeiramente curvado para frente; ginostêmio 3,8-5 mm compr., 2-2,5 mm larg., encurvado; polínias 2, com estipes e viscídio. Frutos 2,5-3,5 cm compr., 0,7-1 mm larg., verdes, fusiformes, ligeiramente encurvados.

Material examinado: BRASIL. MATo Grosso do SuL: Corumbá, Morro Santa Cruz, 24-VI-2002, fr., D.P. Rodriguez 61 (COR, SP).

Material adicional examinado: BRASIL. SÃo PAULO: Botucatu, Sítio do Sr. Antonio de Lala, ca. $1 \mathrm{~km}$ do Distrito de Rubião Júnior, 13-X-1972, fr., A. Amaral Júnior 1179 (BOTU); Campinas, Bosque dos Jequitibás, 17-I-1939, fl., N.G. Blanco s.n. (SP266596); Campinas, Fazenda Santa Eliza, 11-V1994, fr., S.L. Jung-Mendaçolli et al. 170 (IAC, SP); Ilha de São Sebastião, 31-III-1892, fl., G. Edwall s.n. CGGSP 1747 (SP); Itanhaém, Ilha da Queimada Grande, 11-12-IV-1996, fl., fr., V.C. Souza et al. 11040 (ESA, SP); João Ramalho, ca. 6 km da cidade em direção a Rancharia, Haras União, 22 14 '48,5"S, 5048'27,4”'W, fl., fr., 13-II-1996, V.C. Souza \& J.P. Souza 10831 (ESA, SP); Teodoro Sampaio, Reserva Estadual do Morro do Diabo, 15-III-1989, fl., P. Martuscelli s.n. (SP); Tietê, 26-IV-1995, fr., L.C. Bernacci et al. 1558 (IAC, SP).

Oeceoclades maculata diferencia-se das outras espécies ocorrentes na área por possuir folhas coriáceas, maculadas de verde-claro, pseudobulbos unifoliados e flores com calcar clavado, formado pela base do labelo. Oeceoclades maculata é uma das poucas espécies de Orchidaceae que ocorre expontaneamente nos trópicos tanto da África quanto das Américas (Garay \& Taylor 1976). Nas Américas ocorre desde a Flórida (EUA) até o sul do Brasil, Paraguai e Argentina (Stern 1988), passando praticamente por todos os Estados brasileiros. Espécie que, por sua ampla distribuição geográfica, foi repetidamente ilustrada na literatura taxonômica, podendo-se destacar as ilustrações apresentadas por Hoehne (1949 - tab. 150, como Eulophidium maculatum), Dunsterville \& Garay (1959 - pág. 153), Dodson \& Dodson (1980 - tab. 176), Johnson (2001 pág. 137) e Toscano-de-Brito \& Cribb (2005 - pág. 198).

17. Polystachya concreta (Jacq.) Garay \& H.R. Sweet in Howard, Fl. Lesser Antilles, Orchid. p. 178. 1974.

Figuras 22-24 


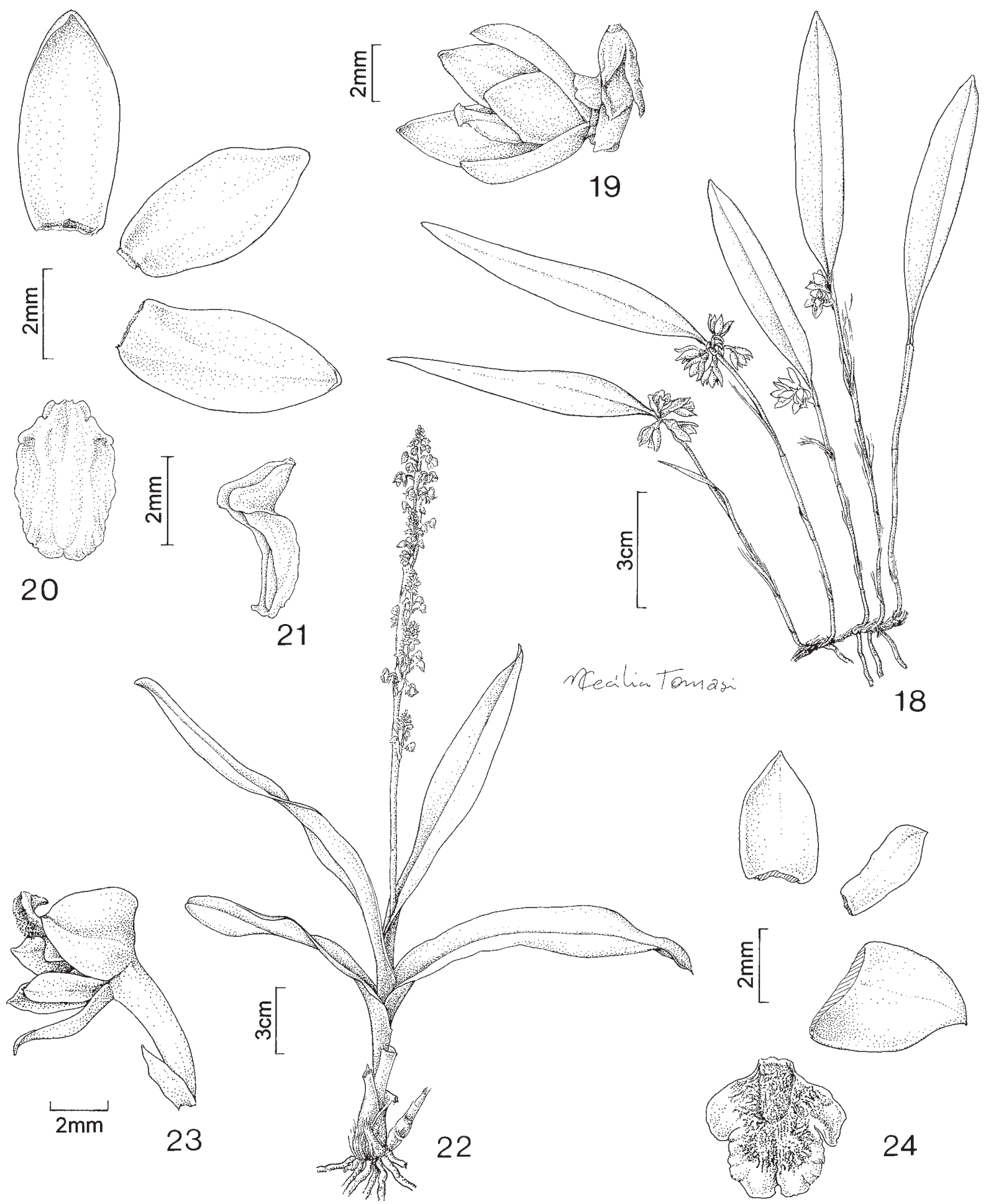

Figuras 18-24. Espécies de Orchidaceae do Morro Santa Cruz. 18-21. Octomeria warmingii Rchb. f. 18. Aspecto geral da planta florida. 19. Flor em vista lateral, com as brácteas florais na base. 20. Peças do perianto distendidas. 21. Labelo em vista lateral. 22-24. Polystachya concreta (Jacq.) Garay \& H.R. Sweet. 22. Aspecto geral da planta florida. 23. Flor em vista lateral. 24. Peças do perianto distendidas.

Figures 18-24. Species of Orchidaceae from "Morro Santa Cruz". 18-21. Octomeria warmingii Rchb. f. 18. Habit of a flowered plant. 19. Flower, lateral view, with floral bracts at base. 20. Perianth, spread. 21. Lip, side view. 22-24. Polystachya concreta (Jacq.) Garay \& H.R. Sweet. 22. Habit of a flowered plant. 23. Flower, side view. 24. Perianth, spread. 
Epífita (holoepífita), simpodial; raízes cilíndricas. Rizoma inconspícuo; cauloma ca. $2 \mathrm{~cm}$ compr., $1 \mathrm{~cm}$ larg., intumescido em pseudobulbo, piriforme-cônico, ereto, 2-4-foliado. Folhas ca. $25 \mathrm{~cm}$ compr., $3 \mathrm{~cm}$ larg., estreitamente oboval-lanceoladas, membranáceas, ápice levemente assimétrico. Inflorescência terminal, ca. 8,5 cm alt., em racemo ou panícula. Flores cremeesverdeadas; pedicelo + ovário ca. $5 \mathrm{~mm}$ compr.; sépalas sub-iguais, ligeiramente concrescidas na base, não formando mento, ovadas, a dorsal ca. $3 \mathrm{~mm}$ compr., $3 \mathrm{~mm}$ larg., as laterais ca. $4 \mathrm{~mm}$ compr., $2 \mathrm{~mm}$ larg.; pétalas ca. $3 \mathrm{~mm}$ compr., $1 \mathrm{~mm}$ larg., lineares; labelo ca. $4 \mathrm{~mm}$ compr., 2,5 mm larg., trilobado, disco com calosidade longitudinal, linear, coberta por um tufo de tricomas brancos; ginostêmio ca. $2 \mathrm{~mm}$ compr., $1 \mathrm{~mm}$ larg., base prolongada em pé distinto, formando um mento evidente com as sépalas laterais; antera subglobosa; polínias 4, ceróides, com estipe e viscídio. Frutos não vistos.

Material examinado: BRASIL. Mato Grosso do Sul: Corumbá, Morro Santa Cruz, 23-IX-1994, fr., M.A.C. Chaparro et al. 9 (COR, CPAP); idem, 23IX-1994, fr., M.A.C. Chaparro \& I.M., Bortolotto s.n. (COR3489, SP271204); idem, 19²4'49"'S, 59²2'47", 4-VII-1998, fr., G.A. Damasceno Junior et al. 1194 (CGMS, SP); idem, 20-I-1999, fl., fr., D.P. Rodriguez 1 (COR, SP); idem, 7-II-1999, fl., fr., D.P. Rodriguez 4 (COR, SP); idem, 19¹1'15.148'S, 57³4'53.081'W, 6-X-2000, fl., G.A.Damasceno Junior 1965 (CGMS); idem, cultivada na Seção de Orquidário do Instituto de Botânica sob nº 17434, 28-I-2003, fl., F. Barros s.n. (SP409464).

Caracterizada por possuir um tufo de tricomas brancos na região do disco do labelo, inflorescência em racemo ou panícula e pseudobulbo com 2-4 folhas. Foi encontrada em matas de galeria em altitudes ao redor de $620 \mathrm{~m}$, em árvores altas, ou em mata fechada, a $740 \mathrm{~m}$ de altitude, sobre árvore a 2-3 m de altura, em condições de pouca luminosidade e alta umidade. Espécie pantropical, com ampla distribuição pela América tropical (Dodson \& Dodson 1980). No Brasil aparece nos Estados do AM, PA, AP, MS, SE, BA, MG, SP, PR, SC e RS.

18. Sarcoglottis curvisepala Szlach. \& Rutk., Ann. Bot. Fenn. 34: 277. 1997.

Terrícola, ereta, áfila na floração. Caule ca. $40 \mathrm{~cm}$ alt., 0,6 cm diâm. na base, cilíndrico, não intumescido em pseudobulbo, na parte superior esparsamente glandular-piloso; bainhas 3,5-4,5 cm compr., aderidas ao caule, membranáceas, ovaltriangulares, ápice acuminado. Folhas ausentes na floração. Inflorescência ca. $13 \mathrm{~cm}$ compr., em racemo, ca. 8-flora, laxa; brácteas florais ca. $3 \mathrm{~cm}$ compr., externamente glanduloso-pilosas. Flores ressupinadas, eretas na metade inferior, depois fortemente arcuadas; pedicelo ca. $6 \mathrm{~mm}$ compr., torcido; sépalas subcarnosas, externamente glanduloso-pilosas, a dorsal ca. $19 \mathrm{~mm}$ compr., 4,5 mm larg., oblongo-lanceolada, côncava, ápice agudo, as laterais ca. $38 \mathrm{~mm}$ compr, 4 $\mathrm{mm}$ larg., ligulado-falcadas, base decurrente no ovário por ca. $22 \mathrm{~mm}$; pétalas $18-19 \mathrm{~mm}$ compr., 2-2,5 mm larg., oblongo-falcadas a espatulado-falcadas, ápice obtuso; labelo distintamente unguiculado, unguículo ca. $4 \mathrm{~mm}$ compr., hipoquílio ca. $18 \mathrm{~mm}$ compr., 7,5 mm larg., linear na parte proximal, com duas aurículas digitiformes retrorsas na base, elíptico cocleado na parte distal, epiquílio ca. 7,5 mm compr., $5 \mathrm{~mm}$ larg., obovado-rombóide, ápice obtuso, crasso; ginostêmio ca. $9 \mathrm{~mm}$ compr., base estendida em um pé retrorso totalmente adnado ao ovário, formando um mento inconspícuo externamente; antera ca. $5 \mathrm{~mm}$ compr., dorsal, rostelo apical, membranáceo, ápice truncado; polínias clavadas, farináceas, dotadas de viscídio. Frutos não vistos.

Material examinado: BRASIL. Mato Grosso do SuL: Ladário, mata ciliar do córrego Bandalta, Fazenda São Marcelo, Rancho do Sr. Bugrinho e arredores, 19¹1'15.148”S, 57³4'53.081'W, 6-X-2000, fl., G.A. Damasceno Junior 1965 (CGMS, SP).

Sarcoglottis curvisepala caracteriza-se principalmente por ser áfila na ocasião da floração, pelas flores externamente glanduloso-pilosas, pelas sépalas laterais muito longas, fortemente encurvadas, com as partes livres quase tão longas quanto as partes basais decurrentes no ovário, e o labelo fortemente encurvado e cocleado no disco. Originalmente descrita para o Estado da Bahia (Szlachetko \& Rutkowski 1997), porém a espécie já foi encontrada em Minas Gerais, Goiás, Distrito Federal (Batista \& Bianchetti 2001) e, agora, também no Mato Grosso do Sul. Uma ilustração da espécie pode ser encontrada em Toscanode-Brito \& Cribb (2005 - pág. 250).

19. Sophronitis cernua Lindl., Bot. Reg. 14: sub tab. 1147. 1828.

Figuras 25-27

Epífita (holoepífita), simpodial; raízes cilíndricas, fasciculadas. Rizoma pouco conspícuo; cauloma 
1-3 cm compr., 0,5-1,5 cm larg., intumescido em pseudobulbo, suborbicular, compresso, prostrado, disposto disticamente ao longo do rizoma, 1 -foliado. Folhas 1,5-3 cm compr., 1-1,5 cm larg., carnosocoriáceas, ovadas, sésseis. Inflorescência terminal, ca. 4,5 cm compr., em racemo, sub-ereta, 3-6-flora; pedúnculo com brácteas pequenas. Flores vermelhas; pedicelo + ovário ca. 2,4 cm compr., 0,2 cm larg.; sépalas ca. $12 \mathrm{~mm}$ compr., $2 \mathrm{~mm}$ larg., lanceoladas, subiguais, livres entre si; pétalas ca. $12 \mathrm{~mm}$ compr., $4 \mathrm{~mm}$ larg., lanceoladas; labelo inteiro, ca. 11 $\mathrm{mm}$ compr., $4 \mathrm{~mm}$ larg., ovado, ápice agudo, base parcialmente tubulosa, envolvendo o ginostêmio, disco amarelo; ginostêmio ca. $8 \mathrm{~mm}$ compr., $2,5 \mathrm{~mm}$ larg.; antera sub-globosa, amarela, maculada de violeta no ápice; polínias 8, ceróides, dotadas de caudícula. Frutos não vistos.

Material examinado: BRASIL. Mato Grosso do SuL: Corumbá, Morro Santa Cruz, 23-IV-1999, fl., D.P. Rodriguez, 5 (COR, SP); idem, cultivada na Seção de Orquidário do Instituto de Botânica sob n⿳ำ 17444, 22-IV-2003, fl., F. Barros s.n. (SP409465).

Caracterizada pelas flores vermelhas, vistosas, labelo com base amarela; inflorescência em racemo curto com 3-6 flores. Encontrada sobre árvores a 1,5-4 $\mathrm{m}$ de altura, a $750 \mathrm{~m}$ de altitude, em floresta com pouca luminosidade e úmida. A espécie está sendo citada pela primeira vez para o Estado de Mato Grosso do Sul, sendo o Município de Corumbá, até o momento, o limite ocidental de ocorrência da espécie, o que permite supor sua possível existência na Bolívia. Sua ocorrência já foi comprovada para o Brasil, Argentina e Paraguai (Instituto de Botánica Darwinion 2009). No Brasil, ocorre nos Estados da BA, ES, RJ, SP, PR, SC, RS, MG (Pabst \& Dungs 1975) e MS.

20. Vanilla palmarum Lindl., Gen. Sp. Orch. Pl. p. 436. 1840

Epífita (hemiepífita), monopodial; raízes nascendo dos nós do caule, cilíndricas, brancas. Caule 2-3,5 mm diâm.; entrenós 3,5-6,5 cm compr. Folhas 8,5-12,5 cm compr., 3,4-4,5 cm larg., subsésseis, patentes, ovadas a ovado-lanceoladas, sub-coriáceas, ápice obtuso, base estreitada em pseudo-pecíolo com 0,4$0,9 \mathrm{~cm}$ compr. Inflorescência axilar, em racemo; pedúnculo mais ou menos flexuoso, às vezes com brácteas foliáceas; brácteas florais ca. $7 \mathrm{~mm}$ compr., ovadas a triangular-ovadas. Flores verde-amareladas com labelo branco e disco amarelo, destituídas de calcar; pedicelo + ovário ca. $3 \mathrm{~cm}$ compr.; sépalas
5-6 cm compr, ca. $1 \mathrm{~cm}$ larg., estreitamente oblongoespatuladas, ápice obtuso, as laterais ligeiramente assimétricas; pétalas ca. 5,5 cm compr., 1,2 cm larg., espatuladas, ápice obtuso; labelo ca. $6 \mathrm{~cm}$ compr., 2,8 cm larg., membranáceo, infundibulado, no $1 / 3$ proximal ungüiculado, margens do unguículo adnadas às margens laterais do ginostêmio, nos $2 / 3$ distais subtrilobado, âmbito obovado-trulado, margens ligeiramente onduladas, ápice fendido, disco com linhas longitudinais espessadas, glanduloso-pilosas; ginostêmio ca. $4 \mathrm{~cm}$ compr., subcilíndrico, alongado, ligeiramente encurvado, estreitando em direção à base, face ventral pilosa; grãos de pólen laxamente unidos, não formando polínias distintas. Frutos não vistos.

Material examinado: BRASIL. MAto Grosso do SuL: Corumbá, Morro Santa Cruz, Balneário Iracema, 21 XI-2004, fl., D.P. Rodriguez \& H. Baracat 60 (COR, $\mathrm{SP})$.

Caracteriza-se por seu hábito hemiepifítico, lianescente e crescimento monopodial e pólen não formando polínias distintas. Ocorre na Venezuela, Colômbia e Brasil (Dunsterville \& Garay 1976). No Brasil, ocorre no PA, MT, BA (Pabst \& Dungs 1975) e MS. A ocorrência desta espécie no Mato Grosso do Sul já havia sido apontada por Hoehne (1915), para a região de Corumbá, e por Pott \& Pott (1994), para o pantanal sul-mato-grossense. Ilustração em Hoehne (1910 - tab. 7; 1945 - tab. 16).

21. Xylobium foveatum (Lindl.) G. Nichols., Ill. Dict. Gard. 4: 225.1887 = Maxillaria foveata Lindl., Edwards's Bot. Reg. 25 (misc.): 2. 1839.

=Xylobium chapadense (Barb. Rodr.) Cogn.,Chron. Orch. 22: 172. 1898 = Maxillaria chapadensis Barb. Rodr., Plant. Mattogr. p. 35. 1898.

Figuras 28-30

Epífita (holoepífita), simpodial; raízes cilíndricas, fasciculadas. Rizoma inconspícuo; cauloma $4-6 \mathrm{~cm}$ compr., 1-1,5 cm larg., intumescido em pseudobulbo, ovóide, ereto, 2-foliado. Folhas 35-47 cm compr., 4-6,5 cm larg., lanceoladas, sub-coriáceas, com várias nervuras longitudinais paralelas, salientes na face abaxial. Inflorescência ca. $12 \mathrm{~cm}$ compr., em racemo, lateral, 7-8-flora; brácteas florais filiformes. Flores de cor creme; pedicelo + ovário ca. 1,6 cm compr., verdes; sépalas ca. $13 \mathrm{~mm}$ compr., 3-4 mm larg., subiguais, ápice acuminado, ligeiramente encurvado e engrossado na face abaxial, a dorsal oblonga a ovado-oblonga, as laterais oblongo- 

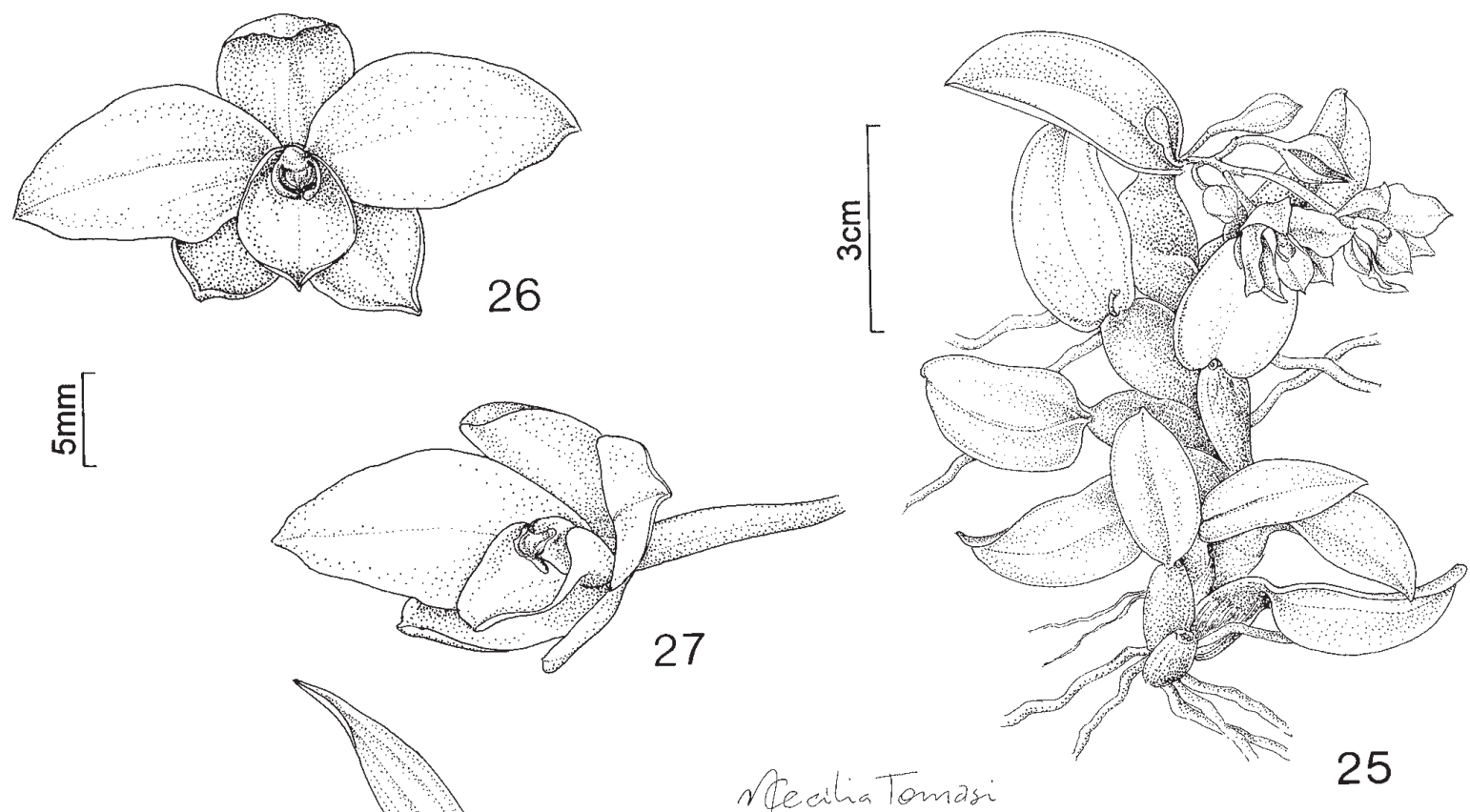

$$
\text { Meciha Tomasi }
$$

\section{5}

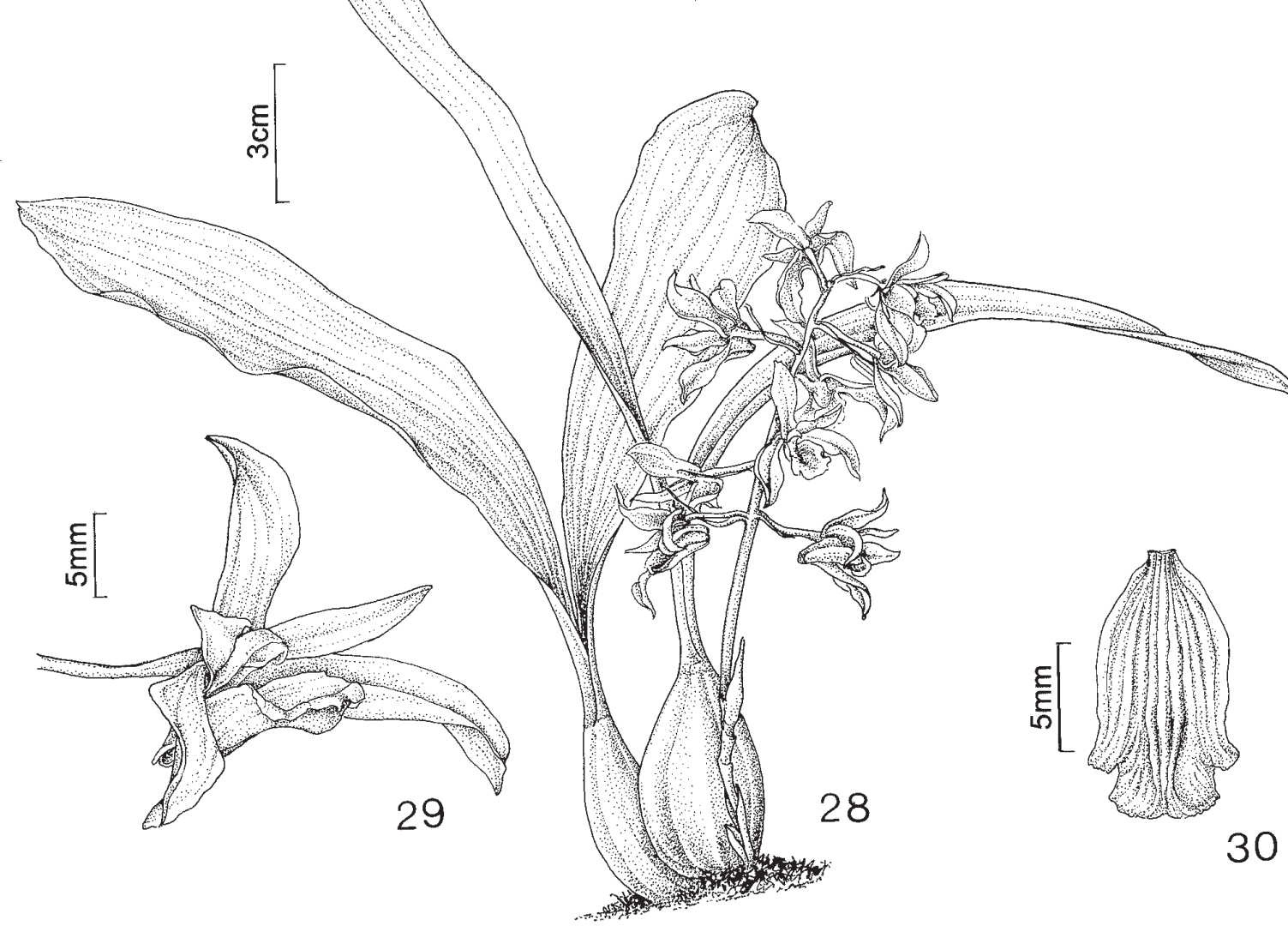

Figuras 25-30. Espécies de Orchidaceae do Morro Santa Cruz. 25-27. Sophronitis cernua Lindl. 25. Aspecto geral da planta florida. 26. Flor em vista frontal. 27. Flor em vista inclinada. 28-30. Xylobium foveatum (Lindl.) G. Nichols. 28. Aspecto geral da planta florida. 29. Flor em vista inclinada. 30. Labelo distendido em vista adaxial.

Figures 25-30. Species of Orchidaceae from "Morro Santa Cruz". 25-27. Sophronitis cernua Lindl. 25. Habit of a flowered plant. 26. Flower, frontal view. 27. Flower, oblique view. 28-30. Xylobium foveatum (Lindl.) G. Nichols. 28. Habit of a flowered plant. 29. Flower, oblique view. 30. Lip flattened, adaxial view. 
assimétricas, ligeiramente falcadas, adnadas na base ao pé do ginostêmio, formando mento; pétalas ca. $13 \mathrm{~mm}$ compr., $2 \mathrm{~mm}$ larg., lanceoladas a falcadas, ápice acuminado; labelo ca. $10 \mathrm{~mm}$ compr., 4 $\mathrm{mm}$ larg., trilobado, membranáceo, envolvendo o ginostêmio, estriado de castanho, articulado com o pé do ginostêmio, lobo central carnoso, côncavo, disco com três carenas longitudinais; ginostêmio ca. $4 \mathrm{~mm}$ compr., base prolongada em pé, ca. $4,5 \mathrm{~mm}$ compr., adnado à base das sépalas laterais, formando um mento conspícuo; antera sub-globosa; polínias 4 , cartilaginosas, dotadas de estipe e viscídio. Frutos não vistos.

Material examinado: BRASIL. MAto Grosso do SUL: Corumbá, Morro Santa Cruz, 23-IV-1999, fl., D.P. Rodriguez 6 (COR, SP); idem, 21-II-2005, fl., G.A. Damasceno Junior et al. 3519 (COR, SP).

Caracterizada pelas sépalas laterais adnadas, na base, ao pé do ginostêmio, formando um mento destacado, pseudobulbos bifoliados e folhas com várias nervuras longitudinais proeminentes. Encontrada sobre árvores a 2,5-5 m de altura em altitude de $740 \mathrm{~m}$ em mata com pouca luminosidade e úmida. Primeira ocorrência para o Estado de Mato Grosso do Sul. Ocorre no Brasil, nos Estados do PA, RO, MT e MG (Pabst \& Dungs 1977), além do MS, e em grande parte da América tropical: México, Panamá, Jamaica, Venezuela, Guiana, Suriname, Guiana Francesa, Colômbia, Equador e Peru (Dunsterville \& Garay 1976, Pabst \& Dungs 1977).

\section{Agradecimentos}

Os autores agradecem à Mineração Corumbaense Reunidas pela permissão de trabalhar em sua área e pelo apoio dado ao primeiro autor, ao Sr. Valter Vitório, dono da Fazenda São Marcelo, pela permissão de coleta em sua fazenda e à Sra. Maria Cecília Tomasi pela confecção das ilustrações. Fábio de Barros agradece à Bolsa de Produtividade em Pesquisa recebida do CNPq (processo 303962/2004-6).

\section{Literatura citada}

Batista, J.A.N. \& Bianchetti, L.B. 2001. Orchidaceae. In: T.B. Cavalcanti \& A.E. Ramos (eds.). Flora do Distrito Federal, Brasil. Embrapa Recursos Genéticos e Biotecnologia, Brasília, pp. 288-307.

Bennett, D.E. \& Christenson, E.A. 1993. Icones Orchidacearum Peruvianum, plates 1-200. A Pastorelli ee Bennett, Lima.
Bianchetti, L.B.\& Batista, J.A.N. 2004. Esclarecimentos sobre as espécies de Cyrtopodium coletadas pela "Comissão de Linhas Telegráficas e Estratégicas de Mato Grosso ao Amazonas". In: F. Barros \& G.B. Kerbauy (orgs.). Orquidologia sul-americana: uma compilação científica. Secretaria do Meio Ambiente, São Paulo, pp. 107-132

Bortolotto, I.M., Damasceno Junior, G.A. \& Isquierdo, S.W.G. 1999. Caracterização das unidades fitofisionômicas da bacia da Lagoa Negra - Ladário - MS. In: II Simpósio sobre recursos naturais e sócioeconômicos do Pantanal: Manejo e conservação. Embrapa Pantanal, Brasília, pp. 283-289.

Braga, P.I.S. 1977. Aspectos Biológicos das Orquidáceas de uma Campina da amazônia central. (AM). Acta Amazonica 7(2 - suplemento): 1-89.

Castro-Neto, V.P. \& Campacci, M.A. 2000. Icones Orchidacearum Brasilienses I. Coordenadoria das Associações Orquidófilas do Brasil, Bauru.

Castro-Neto, V.P. \& Campacci, M.A. 2003. Icones Orchidacearum Brasilienses II. Coordenadoria das Associações Orquidófilas do Brasil, Fernandópolis.

Chaparro, M.A.C. 1994. Levantamento de Orchidadeae Juss. nos Municípios de Ladário e Corumbá - Mato Grosso do Sul. Monografia de graduação de curso. Departamento de Ciências do Ambiente, Universidade Federal do Mato Grosso do Sul, Corumbá.

Cogniaux, A. 1893-1896. Orchidaceae. In: C.F.P. Martius, A.G. Eichler \& I. Urban (eds.). Flora Brasiliensis. Typographia Regia, Monachii, v. 3, pt. 4, pp. 1-672, tab. 1-133.

Cogniaux, A. 1898-1902. Orchidaceae. In: C.F.P. Martius, A.G. Eichler \& I. Urban (eds.). Flora Brasiliensis. Typographia Regia, Monachii, v. 3, pt. 5, pp. 1-663, tab. 1-119.

Cogniaux, A. 1904-1906. Orchidaceae. In: C.F.P. Martius, A.G. Eichler \& I. Urban (eds.). Flora Brasiliensis. R. Oldenbourg, Monachii, v. 3, pt. 6, pp. 1-604, tab. 1-120.

Coutinho, L.M. 1978. O conceito de Cerrado. Revista Brasileira de Botânica 1: 17-23.

Damasceno Junior, G.A. 1998. Levantamento preliminar do terço superficial do morro da Mineração Corumbaense - Corumbá - MS. Relatório de Projeto de Extensão. DAM/CEUC/UFMS, Corumbá.

Damasceno Junior, G.A. 2005. Estudo florístico e fitossociológico de um gradiente altitudinal no Maciço do Urucum -Mato Grosso do Sul - Brasil. Tese de doutorado, UniversidadeEstadual de Campinas, Campinas.

Dodson, C.H. \& Bennett Jr., D.E. 1989. Icones Plantarum Tropicarum, series II, Fascicle 2: Orchids of Peru. Nissouri Botanical Garden, St. Louis.

Dodson, C.H. \& Dodson, P.M. 1980. Icones Plantarum Tropicarum, Fascicles 1-3: 100 orchids of Lowland 
Western Ecuador. The Marie Selby Botanical Gardens, Sarasota.

Dodson, C.H. \& Dodson, P.M. 1989. Icones Plantarum Tropicarum, Series II, Fascicle 5: Orchids of Bolívia. Missouri Botanical Garden, St. Louis.

Dodson, C.H. \& Luer, C.A. 1976. A new Oncidium from Bolivia (Orchidaceae). Selbyana 1: 44-45.

Dodson, C.H. \& Vásquez, R. 1989a. Icones Plantarum Tropicarum, Series II, Fascicle 3: Orchids of Bolívia. Missouri Botanical Garden, St. Louis.

Dodson, C.H. \& Vásquez, R. 1989b. Icones Plantarum Tropicarum, Series II, Fascicle 3: Orchids of Bolívia. Missouri Botanical Garden, St. Louis.

Dressler, R.L. 1981. The Orchids - Natural history and classification. Harvard University Press, Cambridge.

Dressler, R.L. 2005. How many orchid species? Selbyana 26: $155-158$.

Dubs, B. 1998. Prodomus Florae Matogrossensis. Ser. B-3. Betrona Verlag, Küsnacht.

Dunsterville, G.C.K. \& Garay, L.A. 1959. Venezuelan Orchids Illustrated, v. 1. Andre Deutsch, London.

Dunsterville, G.C.K. \& Garay, L.A. 1961. Venezuelan Orchids Illustrated, v. 2. Andre Deutsch, London.

Dunsterville, G.C.K. \& Garay, L.A. 1965. Venezuelan Orchids Illustrated, v. 3. Andre Deutsch, London.

Dunsterville, G.C.K. \& Garay, L.A. 1976. Venezuelan Orchids Illustrated, v. 6. Andre Deutsch, London.

Dunsterville, G.C.K. \& Garay, L.A. 1979. Orchids of Venezuela - an illustrated field guide. Harvard University Press, Alston.

Fidalgo, O.\& Bononi, V.L.R. (coord.). 1984. Técnicas de coleta, preservação e herborização de material botânico. Manual n⿳⺈ 4. Instituto de Botânica, São Paulo.

Forster, W. 2007. Estudo taxonômico das espécies com folhas planas a conduplicadas do gênero Octomeria R. Br. (Orchidaceae). Tese se Doutorado, Universidade de São Paulo, São Paulo.

Garay, L.A. 1980. A generic revision of the Spiranthinae. Botanical Museum Leaflets of Harvard University 28: 277-425.

Garay, L.A. \& Taylor, P. 1976. The genus Oeceoclades Lindl. Botanical Museum Leaflets, Harvard University 24: 249-274.

Hoehne, F.C. 1910. Annexo no 5. História Natural. Botânica. Parte I. Bromeliaceas, Pontederiaceas, Liliaceas, Amaryllidaceas, Iridaceas, Orchidaceas, Aristolochiaceas, Droseraceas e Passifloraceas. Commissão das Linhas Telegráphicas e Estratégicas de Matto Grosso ao Amazonas, Rio de Janeiro.

Hoehne, F.C. 1912. Annexo no 5. História Natural. Botânica. Parte IV. Alismataceas, Butomaceas, Hydrocharitaceas, Pontederiaceas, Orchidaceas e Nynphaeaceas. Commissão das Linhas Telegráphicas e Estratégicas de Matto Grosso ao Amazonas, Rio de Janeiro.

Hoehne, F.C. 1915. Annexo nº 5. História Natural. Botânica. Parte V.Mayacacedas, Xyridaceas, Commelinaceas, Liliaceas, Amaryllidaceas, Iridaceas, Musaceas, Zingiberaceas, Cannaceas, Marantaceas, Burmanniaceas, Orchidaceas, Aristolochiaceas, Phytolaccaceas, Nyctaginaceas, Passifloraceas e Onagraceas. Commissão das Linhas Telegráphicas e Estratégicas de Matto Grosso ao Amazonas, Rio de Janeiro.

Hoehne, F.C. 1938. Cincoenta e uma novas espécies da flora do Brasil e outras descrições e ilustrações. Arquivos de Botânica do Estado de São Paulo, nova série, 1: 1-38, tab. 1-45.

Hoehne, F.C. 1940. Orchidaceas. In: F.C. Hoehne (ed.). Flora Brasilica. Secretaria da Agricultura, Indústria e Comércio, São Paulo, v. 12, pt. 1, pp. 1-254, tab. 1-153.

Hoehne, F.C. 1942. Orchidaceas. In: F.C. Hoehne (ed.). Flora Brasilica. Secretaria da Agricultura, Indústria e Comércio, São Paulo, v. 12, pt. 6, pp. 1-218, tab. 1-137.

Hoehne, F.C. 1945. Orchidaceas. In: F.C. Hoehne (ed.). Flora Brasilica. Secretaria da Agricultura, Indústria e Comércio, São Paulo, v. 12, pt. 2, pp. 1-389, tab. 1-210.

Hoehne, F.C. 1949. Iconografia das Orchidáceas do Brasil. Secretaria da Agricultura, São Paulo.

Hoehne, F.C. 1953. Orchidaceas. In: F.C. Hoehne (ed.). Flora Brasilica. Secretaria da Agricultura, Indústria e Comércio, São Paulo v. 12, pt. 7, pp. 1-397, tab. 1-181.

Instituto de Botánica Darwinion. 2009. Flora del Conosur: Catálogo de las plantas vasculares. http://www.darwin. edu.ar/Proyectos/FloraArgentina/FA.asp (acesso em 14.06.2009).

Johnson, A.E. 2001 . Las orquídeas del Parque Nacional Iguazú. Literature of Latin America, Buenos Aires.

Lima, J.G.A. 1985. Orquídeas do Estado de Mato Grosso. In: L.F. Valle (ed.). II Encontro Nacional de Orquidófilos e Orquidólogos. Expressão e Cultura, Rio de Janeiro, pp.81-99.

Linden, J. 1885. Lindenia: Iconographie des Orchidées, v. 1. F. Meyer-van Loo, Gand.

Lindley, J. 1830-1840. Genera and species of orchidaceous plants. Ridgways, London.

Pabst, G.F.J. \& Dungs, F. 1975. Orchidaceae Brasilienses, v. 1. Kurt Schmersow, Hildesheim.

Pabst, G.F.J. \& Dungs, F. 1977. Orchidaceae Brasilienses, v. 2. Kurt Schmersow, Hildesheim.

Pott, A. \& Pott, V.J. 1994. Plantas do Pantanal. Empresa Brasileira de Pesquisa Agropecuária, Brasília.

Pott, A. \& Pott, V.J. 1999. Flora do Pantanal - listagem atual de Fanerógamas. In: Anais do Simpósio sobre recursos naturais e sócio-econômicos do Pantanal, v. 2, Corumbá. Manejo e Conservação. Embrapa Pantanal, Corumbá, pp. 297-325. 
Pott,A., Silva, J.S.V., Salis, S.M., Pott, V.J. \& Silva, M.P. 2000. Vegetação e uso da terra. In: J.S.V. Silva (ed.). Zoneamento ambiental da borda Oeste do Pantanal: Maciço do Urucum e adjacências. Brasília, Embrapa, pp. 111-131.

Pridgeon, A.M. 1995. The illustrated encyclopaedia of orchids. Timber Press, Portland.

Pridgeon,A.M., Cribb, P., Chase, M. \& Rasmussen, F.N. 1999 Genera Orchidacearum, v. 1. General Introduction, Apostasioideae, Cypripedioideae. Oxford University Press, Oxford.

Ribeiro, J.E.L.S., Garcia, J.P.M. \& Monteiro, R. 1994. Distribuição das espécies de orquídeas na planície litorânea (restinga) da Praia da Fazenda, Minicípio de Ubatuba, SP. Arquivos de Biologia e Tecnologia (Curitiba) 37: 515-526.

Rodrigues, J.B. 1877. Genera et Species Orchidearum Novarum, v. 1. Typographia Nacional, Rio de Janeiro.

Rodrigues, J.B. 1882. Genera et Species Orchidearum Novarum, v. 2. Typographia Nacional, Rio de Janeiro.
Soriano, B.M. 1997. Caracterização Climática de Corumbá - MS. Boletim de Pesquisa 11. Empresa Brasileira de Pesquisa Agropecuária, Corumbá.

Sprunger, S. 1986. Orchids from Curtis's Botanical Magazine. Cambridge University Press, Cambridge.

Sprunger, S. (ed.) 1996. João Barbosa Rodrigues Iconographie des orchidées du Brésil. v. 1: The illustrations. Friedrich Reinhardt, Basle.

Stern, W.L. 1988. The long distance dispersal of Oeceoclades maculata. American OIrchid Society Bulletin 57: 960-971.

Szlachetko, D. \& Rutkowsli, P. 1997. Two new species of the genus Sarcoglottis (Orchidaceae) from Brazil. Annales Botanici Fennici 34: 275-279.

Toscano de Brito, A.L.V. \& Cribb, P. 2005. Orquídeas da Chapada Diamantina. Nova Fronteira, São Paulo.

Werkhoven, M.C.M. 1986. Orchideën van Suriname Orchids of Suriname. VACO, Paramaribo.

Withner, C.L. 1988. The Cattleyas and their relatives, v. 1: The Cattleyas. Timber Press, Portland. 